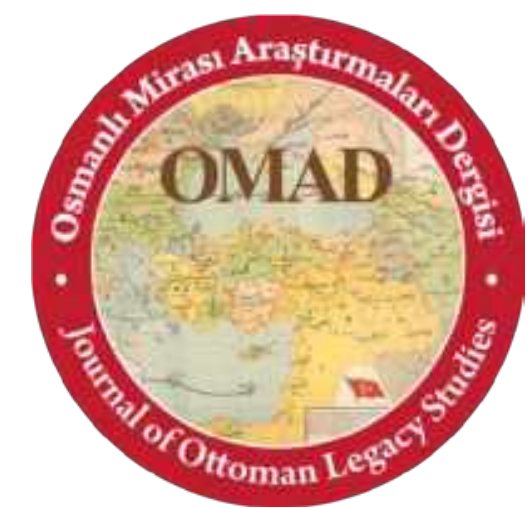

Osmanlı Mirası Araştırmalar Dergisi / Journal of Ottoman Legacy Studies

ISSN 2148-5704

www.osmanlimirasi.net

osmanlimirasi@gmail.com

Cilt 7, Sayı 18, Temmuz 2020 / Volume 7, Issue 18, July 2020

\author{
OSMANLI'DAN CUMHURIYYET'E ISTANBUL FRANSIZ TİCARET \\ ODASININ KURULUŞU VE FAALIYETLERI \\ Activities and Establishment of the French Chamber of Commerce in Istanbul \\ from the Ottoman State to the Republic of Turkey \\ Makale Türü/Article Types : Araştırma Makalesi/Research Article \\ Geliş Tarihi/Received Date : 21.01 .2020 \\ Kabul Tarihi/Accepted Date : 21.05 .2020 \\ Sayfa/Pages : 485-512 \\ DOI Numaras1/DOI Number : http://dx.doi.org/10.17822/omad.2020.168
}

\title{
SÜLEYMAN UYGUN
}

(Doç. Dr.), Ordu Üniversitesi, Fen-Edebiyat Fakültesi, Tarih Bölümü, Ordu / Türkiye, e-mail: suygun27@gmail.com, ORCID: https://orcid.org/0000-0001-6682-6698

\section{$\underline{\text { Atif/Citation }}$}

Uygun, Süleyman, “Osmanlı' dan Cumhuriyet'e İstanbul Fransız Ticaret Odasının Kuruluşu ve Faaliyetleri", Osmantı Mirası Araştırmaları Dergisi, 7/18, 2020, s. 485-512. 



\section{OSMANLI'DAN CUMHURIYET'E ISTANBUL FRANSIZ TICARET ODASININ KURULUŞU VE FAALIYETLERI}

\section{Activities and Establishment of the French Chamber of Commerce in Istanbul from the Ottoman State to the Republic of Turkey}

\section{Süleyman UYGUN}

Öz: 19. yüzyılın ikinci yarısından itibaren çok sayıda yabancı şirket ve müessesenin yayılmasına sahne olan Osmanlı coğrafyasında yaşanan rekabet, muhtelif milletlere ait birçok yeni kurumun açılmasını ve çekişmesini de beraberinde getirdi. Eski ticari alışkanlıklar etrafinda şekillenen münasebetler Sanayi Çağı'nda yerini yeni kurumlara bıraktı. Bu önemli kurumlardan biri de başta İstanbul olmak üzere birçok Osmanlı liman kentinde açılan yabanc1 ticaret odaları oldu. Müteşebbislerinin beklenti ve ihtiyaçlarını karşılamak, sahip olduğu sermayenin örgütlü ve koordinasyonlu bir şekilde yayılmasını sağlamak amacıyla Osmanlı Devleti’ndeki ziraat, ticaret, sanayiye dair tüm bilgi kaynaklarını bünyesinde toplayan yabancı ticaret odaları Osmanlı ekonomisinin şekillenmesinde doğrudan rol oynadı. Bu noktada Osmanlı'dan Türkiye Cumhuriyeti'ne kadarki süreçte İstanbul'da kurulan ve teşkilatlanan Fransız İstanbul Ticaret Odası çalışmaya konu olmuştur.

Anahtar Kelimeler: İstanbul Fransız Ticaret Odası, Türk-Fransız İlişkileri, Yatırım, Tarım, Sanayi

Abstract: Since the second half of the 19th century, the competition in the Ottoman geography, which witnessed the spread of many foreign companies and institutions, allowed the opening and competition of many new institutions belonging to various nations. Relations based on old business were replaced by new institutions in the Industry Age. One of these important institutions was the foreign trade chambers opened in many Ottoman port cities, especially in Istanbul. In order to meet the expectations and needs of the entrepreneurs, the foreign trade chambers which gathered all the information about agriculture, trade and industry as well as organizing and coordinating the spread of capital in the Ottoman Empire played an important role in shaping the Ottoman economy. In this regard, the French Chamber of Commerce, which was established during the Ottoman Empire and existed until the Republic of Turkey, is the subject of this study. Industry

Keywords: French Chamber of Commerce in İstanbul, Turkish-French Relations, Investment, Agriculture,

\section{Giriş}

Üretim araçları ve nakliyatın Sanayi İnkılabı ile yaşadığı olağanüstü değişim klasik dönem ticaret ve üretim alışkanlıklarını da temelden sarstı. Merkantilist kapitalizmden endüstriyel kapitalizme geçişte üretim paydaşları ve araçlarında yaşanan iş paylaşımı, örgütlenme ve disiplin gibi iş hayatının vazgeçilmez yeni unsurları, tedricen liberal ekonomiye dâhil edilen Levant, Karadeniz, Tuna ve art bölgesini, pazar bulma ve pazarı elde tutma rekabeti dolayısıyla, ciddi anlamda etkiledi. Bu değişim, devletler ve şirketlerin yönetim yapısını ve işletmecilik anlayışını zorunlu ve hızlı bir şekilde dönüşüme uğrattı. Siyasi devrimin yerini endüstriyel devrime terk ettiği Sermaye Çağı'nda (The Age of Capital) değişime ayak uyduramayan ya da değişimi yönetemeyen devletler, müesseseler ve şirketler iktisat tarihinin 
gelişim merhaleleri arasında kendilerine küçük bir yer edinerek tarih sahnesinden çekildiler. ${ }^{1}$ Bu çağda endüstri kapitalizminin dünya ekonomisi, temsil ettiği siyasal ve toplumsal düzen ve değerler, onu meşrulaştırır, onaylar görünen fikirler ve inançlar muazzam bir şekilde gelişme gösterdi. Atlantik Avrupası'nın sınai merkezli ekonomik büyümesinin rekabetçi özel girişimi ve hammaddeyi en ucuza alıp mamul ürünü en pahalıya satma başarısına dayanan paradigması etrafında oluşan iktisat anlayışı karşısında klasik üretim ve ticari geleneklere ait iktisadi zihniyet büyük oranda çöktü veya dönüştü. Demir ve kara yolu taşıtlarından, deniz nakliye araçlarına kadar taşımacılığın hızlı güvenli ve ucuz bir şekilde yapılmaya başlanması, Batılı yatırımcıların bakir topraklarda yaşayan toplumlara hatta bireylere ulaşabilmesini kolay ve mümkün kıldı. 19 . yüzyılın ilk yarısına kadar az sayıda ana liman kentiyle ticari münasebetlerde bulunan Batılı tüccar ve müteşebbisler yüzyılın ikinci yarısından itibaren nitel ve nicel yönden artarak tüm Osmanlı liman kentlerine ve hinterlandına yayıldılar. Kapitülasyonlar ve ikili ticaret anlaşmalarının hukuki boyutu ise olabildiğince esnetilerek Batılı tüccar ve yatırımcılarının menfaatlerine göre yorumlandı ve genişledi. Öyle ki Osmanlı coğrafyasında muazzam bir şekilde artan bu şirket ve kumpanyalar imtiyazlar ve anlaşmaları bahane ederek mali sorumluk altına girmeden ve devlete vergi ödemeden Osmanlı iş ve ticaret hayatına atıldılar.

Osmanlı idarecileri ve entelektüelleri, modernleşme sürecinde birtakım önlemler alarak bu duruma reaksiyon gösterseler de bu ekonomik yayılmanın önüne geçemediler. Bilhassa Kırım Savaşı'ndan (1853-1856) itibaren son derece hızlı bir şekilde artan yabancı yatırımcılar, yerli tüccar (Hayriye tüccarı) ve müteşebbisten ziyade kendi aralarında yoğun bir rekabete tutuştu. $^{2} \mathrm{Bu}$ ise başta İngiliz ve Fransız olmak üzere bütün yabanc1 yatırımcı ve tüccarın iş birlikteliği yaptıkları Osmanlı gayrimüslimleri arasında yoğun ve sıkı münasebetleri ve iş paylaşımlarını getirdi. Marsilya Ticaret Odasının merkeziyetçi zihniyet ve koordinasyonuyla Doğu'nun az sayıda ana liman kentine dağılmış olan elçi, konsolos ve Levanten tüccarlardan sağladığı yazışmalar üzerine kurulu iş ve haberleşme ağı, endüstriyel kapitalizm ve liberal ekonominin hızlı ve yayılmacı özelliği karşısında yetersiz ve hantal kaldı ya da bu değişime ayak uyduramadı. Özellikle elçi ve konsoloslardan tedarik edilen bilgiler hızla çoğalan ticaret evleri, şirketler ve kumpanyaların ihtiyaçlarını sağlamaktan uzak kaldılar. Bu devletler tüccar ve yatırımcılarının ihtiyaçlarını karşılayamadığı kentlere kumpanya ve şirket acentelerini konsolos ya da viskonsolos olarak tayin ederek buna çözüm bulmaya çalıştılar, lakin bu uygulama da beklentilere yeterince cevap veremedi.

Doğunun liman ve iskele kentlerine dağılan küçük sermeyeli ticaret evleriyle (La Maison de Commerce) başlayan pazar ve inhisar oluşturma süreci; ekonomi, siyaset, misyonerlik, kültür ve hukuk gibi muhtelif sahalardaki kurum ve müesseselerin uyumu içerisinde büyüyen ve gelişen kolektif, komandit, anonim, kartel, hatta tröst şirket ve kumpanyalara dönüştü. ${ }^{3}$

Yabanc1 şirketlerle rekabet edecek gücü ve tecrübesi olmayan yerli müteşebbis, zanaatkâr ve tüccarların hayli azaldığı bu süreçte devlet kendine mahsus millî bir iktisadi siyaset belirleyemedi. Osmanlı idarecileri her şeye rağmen yerli müteşebbisleri destekleyici bazı tedbirler alarak direniş gösterdiler. Batı sermayesinin kurum ve müesseselerini kendi imkânları

\footnotetext{
${ }^{1}$ Hobsbawm emperyal yayılma dönemini Sermaye Çağı olarak nitelendirmektedir. E. J. Hobsbawm, The Age of Capital 1848-1875, Weidenfeld and Nicolson Ltd. London 1975, s. 14; ayrıca Türkçe çevirisi için bkz. Hobsbawm, Sermaye Çă̆ 1848-1875, çev. Bahadır Sina Şener, Dost Yay., İstanbul 2003, s. 13-14.

${ }^{2}$ Çalışmanın giriş bölümünde ele alınan husus üzerine şüphesiz çok sayıda müstakil çalışma söz konusudur. Giriş bölümü bu güne kadar yapılmış olan müstakil okumaların çalışma konusuyla iltisaklandırılmış rafine bir hülasasıdır. Bu hususta kıymete değer eserlerin içerisinden çok küçük bir kısmı şunlardan ibarettir: Ali Akyıldız, Anka'nın Sonbaharı Osmanlı'da İktisadi Modernleşme ve Uluslararası Sermaye, İletişim Yay., İstanbul 2005, s. 185-186; Keza Donald Quataert, Osmanlı Devleti'nde Avrupa Íktisadi Yayılımı ve Direniş (1881-1908), çev. Sabri Tekay, Yurt Yay., Ankara 1897, s. 15-16; Şevket Pamuk, Osmanlı Türkiye İktisadi Tarihi, İletişim Yay. İstanbul 2003, özellikle 189-213. sayfalar, Bilhassa yabancı yatırımlar için Necla Geyikdağı, Osmanlı Devleti'nde Yabancl Sermaye 1854-1914, Hil Yay., İstanbul 2008, s. 91-118.

${ }^{3}$ Süleyman Uygun, “Modern Mısır'ın Doğuşu (Yatırım, Kredi ve İflas Denklemi'nde) ve Bir Fransız Aktör: Edouard Andre Dervieu”, Studies of the Ottoman Domain, C. IX, S. 17, Ağustos 2019, s. 95.
} 
ile Osmanlı ekonomisine kazandırmaya çalıştırlar. Bu bağlamda 1880 y1lında İstanbul Ticaret Odası gibi ticari müesseseler kurarak Osmanlı tüccarı, zanaatkârı ve sanayicileri arasındaki münasebetleri arttırıp yerli bir iktisat politikası izleme yoluna gittiler. Lakin Batılı şirket ve kumpanyalar ile ticari ve iktisadi münasebetlerde bulunan ve kendi çıkarları ile geleceklerini bu yabanc1 şirketlerde gören gayrimüslim zümrelerin büyük çoğunluğu 1870'lerden itibaren kurulmaya başlayan yabancı ticaret odalarının asil, tali ve gönüllü üyeleri oldukları için bu üyeler genellikle bağlı bulundukları yabancı sermayenin menfaat ve beklentileri doğrultusunda hareket ettiler. Osmanlı ekonomisinde mühim bir yere sahip olan Fransızlar da İngilizler ve diğer Batılı devletlerden ilham alarak ilk yurt dışı ticaret odası tecrübelerinden birini İstanbul'da 10 Ekim 1884 tarihinde kendilerine mahsus bir ticaret odası açarak tecrübe ettiler ve hayli başarılı oldular. Bunda 1881 Muharrem Kararnamesi'yle yabancı alacaklılara teslim edilen Osmanlı maliyesinin gayrimüslim tüccara sağladığı daha fazla avantajın da etkisi vardı. ${ }^{4}$ Elçi, konsolos ve acentelerin tutanak ve raporlarından yetersiz ve düzensiz olarak temin edilen iktisadi, istatistiki bilgiler, bundan böyle İstanbul Fransız Ticaret Odası ve hemen akabinde Çanakkale, Bursa, İzmir, İskenderiye gibi önemli merkezlerde açılan Fransız ticaret odaları ve 20. yüzyılın ilk yarısında sayıları bin civarına ulaşan üyeleri ile periyodik olarak her ay yayımladıkları bülten tarafından daha düzenli, disiplinli ve sistemli bir şekilde sağlandı. Aynı zamanda elçi, konsolos ve viskonsoloslar bu odaların doğrudan onursal başkanları (Président d'Honneur) oldukları için bu müesseseler tarafindan edinilen ticari ve sınai yatırım bilgileri de ticaret odalarının ve üyelerinin hizmetine sunuldu. Bu sayede Osmanlı'daki Fransız ticaret odaları, Fransız millî sermayesinin Osmanlı coğrafyasında yayılması, örgütlenmesi ve münasebetlerinde hayati öneme sahip bir kurum oldu. 1884 yllından itibaren Osmanl1 coğrafyasında ticaret ve yatırım yapmak isteyen Fransız tüccar ve müteşebbislerinin başvurdukları ve sorumlu oldukları yegâne mercilerden biri Fransız siyasi kurumları ile müşterek hareket eden Fransız ticaret odaları oldu.

Çalışmada Levant ve Karadeniz liman kentlerinde ve art bölgelerinde Fransız yayılmacılığının önemli bir kurumsal ayağı olan İstanbul Fransız Ticaret Odasının ele alınmıştır.

\section{İstanbul'da Fransız Ticaret Odasının Kurulması (10 Ekim 1884)}

Osmanlı İmparatorluğu'nda son dönem yabanc1 ticaret müesseselerinin kurumsallaşmasının en önemli kanıtlarından biri hiç şüphesiz yabancı ticaret odalarıydı. Batılı devletlerdeki liberal ekonomi etrafinda kurumsallaşmaya başlayan ticaret odaları gibi yapılanmaları, Osmanlı İmparatorluğu ancak 1880 gibi geç bir tarihte yakalayabilmiştir. Aslında her ne kadar ticaret odalarını kısmen andırsa da esnaf ve sanayi müesseselerini denetim altında bulunduran loncalar kısmen benzeri görevi ifa etmekteydiler. Ancak yapısı itibarıyla loncalar, ticaret odalarından çok farklı idiler. Etkinliği ve işlevi 19. yüzyılda hayli zayıflayan lonca sistemi liberal ekonomi anlayışına uyum sağlayamadığı için yavaş yavaş yeni usul örgütlenme biçimi olan ticaret, ziraat ve sanayi odalarına bırakmaya başlamıştır. ${ }^{5}$

Serbest piyasa ekonomisindeki kurumsallaşma sürecine dâhil olmak durumunda kalan Osmanlı idarecilerinin yerli ticaret odası gibi önemli bir müesseseyi kurma çalışmaları dönemin sadrazamı Mehmed Said Paşa tarafından fiilen 1879 yılında başlatıldı. ${ }^{6}$ Said Paşa'nın direktifleri üzerine Fransa'daki gibi ticaret odalarının İstanbul'da da kurulması için 11 maddelik bir taslak hazırlandı ve bu taslak 18 Ocak 1880 tarihinde dönemin hükümeti tarafından kabul edildi. Böylelikle Dersaadet Ticaret Odası, Sultan Abdülhamid'in onayıyla 19 Ocak 1880 gibi

\footnotetext{
${ }^{4}$ Şevket Pamuk, Osmanlı Türkiye İktisat Tarihi 1500-1914, İletişim Yay., İstanbul 2007, s. 231-232.

${ }^{5}$ Murat Koraltürk, “Osmanlı Devleti’nde Ticaret ve Sanayi Odalarının Kuruluşu ve Gelişimi”, Yeni Türkiye Osmanlı, C. III, Yeni Türkiye Yay., Ankara 1999, s. 449. (449-458)

${ }^{6}$ Chambre de Commerce d'Istanbul, Anné 125, Istanbul 2006, s. 3-5; Ufuk Gülsoy-Bayram Nazır, Türkiye'de Ticaretin Öncü Kuruluşu, İstanbul Ticaret Odası 1923-1960, İstanbul Ticaret Odası Yay., İstanbul 2012, s. 13.
} 
geç bir tarihte ancak kurulmuş oldu. ${ }^{7}$ Odanın kuruluş mevzuatında Fransız ticaret odalarındaki gibi ticaret, endüstri, kültür ve sanatın gelişimine ayrı bir ehemmiyet verilmişti. Bu amaçla 15 günde bir Dersaadet Ticaret Odası Gazetesi adıyla yayın hayatına giren mecmuanın ilk nüshası 5 Ocak 1885 tarihinde yayımland1. ${ }^{8}$

Fransa'da ise ilk olarak açılan Marsilya Ticaret Odasının kuruluşu 1599 gibi çok erken bir tarihe tekabül etmektedir. ${ }^{9}$ Ancak Fransız ticaret odalarının yabancı ülkelerde açılması çok geç bir tarihte 19. yüzyılın son çeyreğinde olmuştur. Yabancıların İstanbul'da Ticaret Odası açmaları ise 1870 'li yıllara tesadüf etmektedir. İstanbul'da Avusturyalılar 1870 yılında konsolosluklarının bünyesinde bir ticaret odası açtılar. İtalyanlar da yurt dışındaki ilk ticaret odalarını 1883'te İstanbul'da açmışlardır. ${ }^{10}$ Akabinde ise Fransızlar, İngilizler (1887), Amerikalılar, Yunanlar, Hollandalılar ve Ruslar gibi birçok Batılı devlet başta İstanbul olmak üzere İskenderiye, İzmir, Selânik, Beyrut, Mersin, Trabzon gibi çok sayıda liman kentlerinde ticaret odaları açtılar. ${ }^{11}$ O kadar ki 1908 yılına gelindiğinde Osmanlı vilayet, sancak ve kaza merkezlerinde bulunan yabancı ticaret odalarının sayısı 160 'a yükselmişti. ${ }^{12}$

Osmanlı memleketlerinde yabancı ticaret odalarının açılmasını Osmanlı bürokrasisi ilk olarak tepkiyle karşıladı. Ancak Batı ekonomik kurumlarına karşı verilen çoğu tepkilerde olduğu gibi bu tepkilerin hukuki manada yaptırımlara dönüşmesi imkânsız oldu. Hariciye Nezareti ve İstanbul Ticaret Odası, yabancı ticaret odalarının kurulması hakkında fikir alışverişinde bulundular ve görüsslerini Babıali'ye sundular. Verilen tepki ve alınması gereken önlem kısaca şu şekilde ifade edilmekteydi:

\begin{abstract}
Muntazam Osmanlı Ticaret odası mevcut olduğu hâlde müstakil olarak ecnebi menfaatiyle iştigal edecek bu misillü cemiyetlerin teşkilinden bazı mahsurlar doğacağı tasdik edilmekle beraber ecnebi bir devlet şubesinde bulunan ticaret, kendi ticaretlerinin terakkisine hizmet etmek üzere aralarında bir nevi meclis teşkil etmelerine ve açıktan açığa muhalefet etmeleri hususunda tereddüt eder ve hükümet-i seniyyeye tavsiyede bulunuruz. Bu cemiyetlerin maksadının ticarete zarar verecekleri salim olup, umumi düzene ve devletin hukukuna zarar vermedikçe bundan bir diplomasi meselesi çıkarmaya da lüzum yoktur. Bunların kapatılmasını talep etmeye de imkân yoktur. Osmanlı Ticaret Odasının bu mesele hakkındaki raporuna göre Avrupa devletlerinde dahi resmî ticaret odalarından başka bu türden ecnebi ticaret odaları mevcuttur. Lakin bir tedbir olmak üzere memalik-i şahanedeki ecnebi ticaret odalarının faaliyetlerini ve nüfuzunu denetim altında tutabilmek için bir ferman-1 alinin çıkarılması bunların faaliyetlerini resmî bir denetime tabi tutacaktır. ${ }^{13}$
\end{abstract}

Öncülüğünü İngilizlerin çektiği, diğer Batılı devletlerde olduğu gibi Fransızların da yabanc1 ülkelerde ticaret odası açma fikri 1873'te İngilizlerin Paris'te İngiliz Ticaret Odası (Paris British Chamber of Commerce) açmalarıyla ortaya çıktı. Bundan sonra Fransız idareciler ve müteşebbisler de yabancı ülkelerde bir an önce ticaret odaları açılması fikrini ileri sürmeye başladılar. Bunun üzerine Fransızlar ilk olarak Nouvelle-Orléans, Londra, Montevideo ile Lima'da ticaret odaları açtılar ve bu odalar başarılı bir şekilde faaliyetlerini gerçekleştirdiler. ${ }^{14}$ Böylelikle iyi ve doğru bir şekilde işleyen ticaret odalarının ticari hususlarda, ticari davalarda ve anlaşmazlıklarda, istatistiki bilgilerde ve uluslararası bağlantılarda Dışişleri Bakanlığı ve konsolosluklardan daha başarılı oldukları tespit edildiğinden ticaret odalarının ehemmiyeti

\footnotetext{
7 İlber Ortaylı, Lonca'dan Odaya: İstanbul Ticaret Odası'nın 125 Y1l Anısına, İstanbul Ticaret Odası Yay., İstanbul 2006, s. 12-14.

${ }^{8}$ Gülsoy-Nazır, Türkiye'de Ticaretin Öncü Kuruluşu, s. 62.

9 Répertoire des Travaux de la Société de Statistiques de Marseille, Publié sous la Direction de Adrien Sicard, Marseille 1890, s. 34, Ayrıca Marsilya Ticaret Odasının resmî sitesindeki kuruluş tarihi için de bkz. https://www.cci.fr/web/organisation-du-reseau/histoire, erişim tarihi 25.07.2019.

${ }_{10}$ Osman Öndeş, Vapur Donatanları ve Acenteleri Tarihi, İMEAK Deniz Ticaret Odası, İstanbul 2013, s. 147.

${ }^{11}$ Gülsoy-Nazır, Türkiye’de Ticaretin Öncü Kuruluşu, s. 29-34.

${ }^{12}$ Zafer Toprak, "Osmanlı’da Ecnebi Ticaret Odaları”, Finans Dünyası, Şubat 1990, s. 78-79.

${ }^{13}$ BOA. HR. TO. 368/67, 24 Ocak 1870.

${ }^{14}$ Le Journal des Chambres de Commerce Revue Mensuel, Decembre 1883, 2. Année, N. 12, s. 606-607.
} 
anlaşıldı. Zaten konsoloslukların bünyesi, yapısı ve işleyişi her ne kadar değişse de Batı ekonomisinin çıkar, ihtiyaç ve yayılmacılığını sağlayan pazarlar, ticaret ağları ve her geçen gün yapısı ve içeriği farklılaşan ticari davalar vs. üzerine talep edilen ayrıntılı malumat ve brifinglerde konsoloslukların yetersiz kalması ticaret odaları adı altında bu yeni oluşumların önemini ortaya çıkarmıştı. Dolayısıyla ticaret odaları, konsoloslukların yetersiz kaldıkları ticaret, sanayi, nakliyat, uluslararası ticari ilişkiler, markalaşma, patentleşme, kültürel ve hukuki konular hakkında muhataplarını bilgilendirmek, onları yönlendirmek, siyasi ve hukuki bağlantılarını sağlamaya yönelik bir misyona sahip oldular.

Fransız ticaret odalarının daimî onursal başkanı (Président d'Honneur) yine Fransız diplomatik kurumlarının temsilcileri olan konsoloslardan oluşmaktaydı. Her ne kadar Fransız ticaret odalarının kuruluşlarında başlıca aktör olsalar da Fransız elçi ve konsoloslar, odanın bağımsız yapısına ve liberal işleyişine zarar vermemek gayesiyle her zaman Président d'Honneur adıyla anılan onursal başkanlık görevlerini etkin bir şekilde ifa ettiler. Bu nedenle Fransız diplomatik kurumları ve ticaret odaları arasında çok sıkı münasebetler söz konusuydu. Biri diğerinin yardımc1, tamamlayıcı görevini üstlenmekteydi.

İhtiyacı her geçen gün daha fazla hissedilen ticaret odalarının yabancı ülkelerde kurulması fikri, gerek sermayedarlar, tüccarlar, sanayiciler, gerekse de diplomatik müesseselerde yoğun bir şekilde tartışılmaktaydı. Bu amaçla yabancı ülkelerde Fransız ticaret odalarının açılması için Dışişleri Bakanlığı bünyesinde bir komisyon oluşturuldu. Komisyonda bilhassa İstanbul olmak üzere birçok önemli liman kentinde ticaret odasının kurulması kararlaştırıldı.

$\mathrm{Bu}$ maksatla 1880'li yılların başlarında Fransız İstanbul konsolosunun girişimiyle İstanbul'da ticaret odası kurma hazırlıkları yapıldı. Aynı anda İskenderiye, Odesa ile diğer Karadeniz ve Levant limanlarında ticaret odaları açmak için çalışmalar yapmaktaydılar. ${ }^{15}$

Fransız Dışişleri Bakanlığı bünyesinde yapılan toplantıda öncelikli olarak açılması planlanan ticaret odalarının önemli bir şubesinin İstanbul'da olmasına karar verildi. Alınan karar gereği Fransız İstanbul Konsolosu M. Alphonse Gazay, hemen girişimlere başladı. Konsolosun isteği üzerine 1883 yılında bir komisyon kuruldu, Fransız Ticaret Bakanının da bulunduğu bu toplantıda, yabancı ülkelerdeki Fransız ticaret evlerinin güncel sorunları ve ihtiyaçları üzerinde duruldu. Komisyon bu projenin avantajlı olabilecek noktalarını belirleyerek bu konuda gerekli araştırmalar yapılması isteğinde bulundu. Bunun üzerine İstanbul Konsolosu Gazay, İstanbul'un önde gelen Fransız ve tabiiyetindeki tüccarlar ve girişimcileri bir toplantıya davet etti. 1883 Haziran" ayında tüccarların da oy birliğiyle İstanbul'da ticaret odasının kurulması kararlaştırıldı. İstanbul'daki Fransız tüccarların bu düşüncesini Fransız kolonilerinde bulunan ticaret odalarının çoğunluğu destekledi. Bunun üzerine konsolos bu projeyi teyit etti. Bundan bir y1l sonra Ticaret odasının açılması için ilk resmi toplantı 29 Ağustos 1884 Cuma günü Fransız konsolos A. Gazay, başkanlığında M. Bloch, Briata, Thouzey, Rigaudias, Décugis, Venel, Mille, Tubini adlarında üyelerin eşliğinde toplanıldı. Odanın bu ilk toplantısı Tom-tom adlı sokakta bulunan Fransız Konsolosluğu binasında yapıldı. 1886'da ise Ticaret Odasının sekreterlik bürosu geçici olarak Galata'da Kuyumcular Hanın ikinci katında bulunan 1 numaralı daire olarak seçildi. Aynı yı1 yine Galata'da Ticaret Han'da bulunan 14 numaralı daha geçiş bir büro kiralandı ve burada daimî olarak istihdam edilen bir işçi alındı. 1896'dan itibaren bu büroya yeni salonlar ve taşınmazlar eklendi ve oda faaliyetlerine burada devam etti. ${ }^{16}$

\footnotetext{
${ }^{15}$ Le Journal des Chambres de Commerce Revue Mensuel, Decembre 1883, 2. Année, N. 12, s. 606-607.

* İstanbul Ticaret Odası Tüzüğü'ne dair hazırlanan raporun basım tarihi 1884, Tüzük metninin içerisinde ise geçen y1l haziran ayında konsolos ile soylu tüccarların bir toplantı yaptığından söz etmektedir. Buradan ilk toplantının 1883 haziran ayında yapıldığı anlaşılmaktadır.

${ }^{16}$ Notice Historique sur la Chambre de Commerce Française d'Istanbul, s. 2.
} 
Toplanan komisyon, Ticaret Odasının kurulması için 1 yıl önce belirlemiş olduğu tespitler, ihtiyaçlar ve sorunlar hakkında yazılan raporlar üzerinde durdu. Komisyonun onursal başkanı olan Fransız İstanbul Konsolosu A. Gazay, proje taslağı ve önerisini değerlendirmesi için 5 kişilik muhtelif üyelerden oluşan bir üst komisyonun seçilmesine karar verdi. Bu üyeler proje taslağından sorumlu olacak, İstanbul'da hangi hükümlerin uygulanabileceğini göz önünde bulunduracak, uygulanması zor, yararsız ve imkânsız görünen hükümleri dikkate alarak belirtecektir. Bu beş kişilik komisyon şunlardan oluşmaktaydı: M. Bloch, Briata, Mille, Giraud adlarında Fransız tüccarlar ve Oerti adında Fransa ile iltisaklı deri ve kürk ticareti yapan İsveçli bir tüccar. ${ }^{17}$ Giraud, Briata komisyonculuk, pamuklu ve yünlü kumaş ticareti, Mille ise La Foncier Kumpanyası 'nın direktörü ve aynı zamanda gül yağı distribütörüydü. ${ }^{18}$

Adı geçen 5 kişilik komisyonun sunduğu rapordan sonra Fransız konsolosunun başkanlığında 6 Ekim 1884 yılında İstanbul'un önde gelen Fransız ve Osmanlı Gayrimüslimi olup Fransız tabiiyetindeki tüccarların katılımıyla İstanbul Ticaret Odasının kurulması için nihai toplantı yapıldı. Toplantıda üst komisyon üyeleri şu kişilerden oluşmaktaydı. M. Tricon, Mille Sylvain, Briata, Giraud, ${ }^{19}$ Bertin, Dumas, Aubert, Moussat, Rigaudias Louis, Duval, Venel, Battus, Touzel, Daffes, Glavany, Bourcier. Üst komisyon bu güne kadar şekillenen taslak tüzüğün maddeleri üzerinde tartıştı, taslak üzerinde küçük değişiklikler yapıldıktan sonra aşağıdaki başlıkları ihtiva eden odanın kuruluş nizamnamesi kabul edildi:

\section{İstanbul Fransız Ticaret Odasının Kuruluş Nizamnamesi}

Nizamname toplamda 17 maddeden oluşmaktaydı. Kuruluş nizamnamesinin içeriği özetle şu başl1klardan oluşmaktaydı:

Madde 1. Ticaret odasının üyelerinin tamamı mevcut yasalara uymaları şartıyla, İstanbul'a yerleşen Fransızlar ile Fransız himayesinde bulunan tüccar, sanayici ve finansal kuruluşların yöneticilerinden oluşacaktır.

Madde 2. İflas hâlinde veya usulsüz işlerde bulunan ve iflas takibinde olan kişiler odanın bir parçası olamaz.

Madde 3. Genel toplantıya katılan üyeler genel tüzüğe uygun olarak tüccar, sanayici ve Fransız finansal yöneticilerden / şeflerden seçilir. Üyeler, meclis üyelerinin genel çoğunluğunun reyiyle genel toplantıda seçim yolu ile seçilir. Kolektif şirketten iki ortak aynı kurulda görev alamaz.

Madde 4. Meclis 12 üyeden oluşur ve üç yıllığına seçilir, seçim üç yılda bir tekrarlanır. $\mathrm{Bu}$ üyeler ihracat, ithalat ve perakende ticaretin yanı sıra sanayinin çeşitli dallarını temsil etmek zorundadırlar.

Eski üyeler yenilenen seçimlerde yeniden seçilebilirler.

Seçilecek üyelerin vasfi:

\footnotetext{
${ }^{17}$ ACCIM. MQ55/104, La Création d’une Chambre Française a Constantinople, août-octobre 1884.

${ }^{18}$ Chambre de Commerce Française de Constantinople Bulletin Memsuel, 1. Année, N. 7, Constantinople, 20 Octobre 1887.

${ }^{19}$ Ernest Giraud, Giraudlar ailesinden gelmekte olup, Cezayir, İstanbul ve Marsilya arasında ticari münasebetlerle ilgilenmektedir. Özellikle Ernest Giraud İstanbul ticaretinde saygın bir yere sahip olup daha sonra İstanbul Ticaret Odası başkanlığ 1 ve konsolos yardımcılığı gibi görevlerde de bulunmuştur. Department of Commerce and Labor, No. 2294, Daily Consylar Reports, June 27, Goovernment Printing Office, Washington 1905, s. 2. Revue des Commerce, C. IV, Paris 1909, s. 84; Dalloz, Jurisprudence Generale, Bureau de la Jurisprudance generale, Paris 1902, 295. Aynı zamanda Giraud kardeşlerin bir ticaret kumpanyası da vardır. Giraud ailesine mensup olan Hubert Giraud Marsilya'da vapur nakliyat şirketlerinin gelişimine dair kapsamlı bir eser kaleme almıştır. Giraud Hubert, Les Origines et l'Evolution de la Navigation a Vapeur a Marseille (1829-1900), Societe Anonyme du Semoplhore de Marseille 1929.
} 
İstanbul'da meskûn tüccarlar, sanayiciler ile Fransız finans kurumları şefleri ve Fransız himayesinde bulunan, en az 25 yaşında olup ticaret ve endüstri sahasında üç yıl deneyime sahip olanlardan seçilecek.

Meclis aşağıdaki üyelerden oluşacak ve yeni seçimlere kadar görevde kalacaklardır.

$\begin{array}{ll}\text { MM. Sylvain Mille } & \text { MM. Pierre Bourcier } \\ \text { Emile Dumas } & \text { Ernest Giraud } \\ \text { Robert Briata } & \text { Constantin Duval } \\ \text { Antoine Mousssat } & \text { Leon Lemoine } \\ \text { Alphonse Lebet } & \text { Charles Bertin } \\ \text { Hippolyte Aubert } & \text { Jean Thouzery }\end{array}$

Madde 5. Başkan, sekreter ve veznedar konsey tarafından seçilir. Başkanın olmaması durumunda yerine konseyin en yaşlı üyesi vekâleten bakar. Yönetim kurulu üyesi sekreter ve veznedarın görevleri ücretsizdir.

Madde 6. Odadan çıkan tüm belgeler başkan tarafindan ve duruma göre sekreter ile veznedar tarafindan da imzalanır.

Madde 7. Fransız konsolosu Ticaret Odasının onur konuğudur genel kurul toplantılarına, konseyin oturumlarına başkanlık edebilecek yetkiye sahiptir.

Madde 8. Meclis, Fransız tüccarları ve Fransız himayesinde olanların kaydını tutar.

Madde 9. Genel kurul yılda bir defa toplanır, kurul görev süreci hakkında rapor verir ve gündemle ilgili o gün konuşulacak konuları 8 gün önceden konsolosa bildirir. On üyenin yazılı talebi üzerine, başkan olağanüstü genel kurul toplantısı yapmak zorundadır.

Madde 10. Meclis toplantıları ayda bir kez yapılır, Meclis gerektiği durumlarda daha sık toplantı yapılmasına karar verebilir.

Madde 11. Büro, yayın vs. harcamaları için 10 franklık sabit oda üyelik ücreti ile 10 franklık yıllık abonelik ücretinden temin edilecektir.

Madde 12. Yıl boyunca aidat ödemeyi ihmal eden bir üye meclis üyesi olmaktan çıkarılacak, ancak 20 frank cezai bedel ödeyerek yeniden üye olabilecektir.

Madde 13. Fransız ticaret odas1, meclis tarafindan temsil edilecektir.

Konseyin aşağıdaki sorumlulukları vardır:

-Fransız ticaretinin faydasına olan tüm bilgileri toplar.

-Bir yerin işleyişi ve hukuki mevzuatı hakkında Odadan ne zaman görüş talep edilirse öneri ve bilgi vermekle mükelleftir.

-Gümrük, ulaştırma ve diğer genel meseleler hakkında Fransız ve Osmanlı makamlarına sunulması gereken raporları ve notları konsolos aracılığıyla gerekli makamlara sunar.

-Bu raporlar, Fransız Ticaret Odası ve diğer ülkelerle temasa geçmek için sunulur.

-Osmanlı İmparatorluğu'ndaki Fransız ticaretini ve Fransa'daki Türk ticaretini geliştirmek için araştırmalar ve etütler yaptırır.

-Araştırmalar yapmak ve Fransız fabrikalarında üretilen ürünlerin marka sahteciliğini bildirmekle mükelleftir.

-Bir mekânın ticari olarak kullanımı için görüş sunar. 
-Ticari hususlarda oda bünyesinde bulunan üyelere, hakemlik ve uzlaşı konusunda yardımda bulunur.

Madde 14. Ticaret Odasının metropol idarecileri ve yerel yönetimlerle iletişimde bulunması Fransız Konsolosluğu tavassutuyla olacaktır.

Madde 15. Talep üzerine ticari ve endüstriyel bilgiler için, başkan konuyu önceden incelemek ve kurulun olağan oturumunda değerlendirmek üzere üç üyeden oluşan bir komisyon tayin eder.

Madde 16. Bütçe komitesi, büronun beslenme ve diğer harcamaları için yapılan harcamaları genel kurul toplantısında sunar.

Madde 17. Meclis üyelerinin bir kısmının yıllık olarak yenilenmesi ve tavsiye edilen deneyimlere göre statülerinin belirlenmesi için, toplantıya katılan üyelerin çoğunluğu, kayıtlı seçmen sayısının en az 2/3 oranında olmalıdır. Meclis daha sonra gizli oyla konsey üyelerinin seçimine gider. $^{20}$

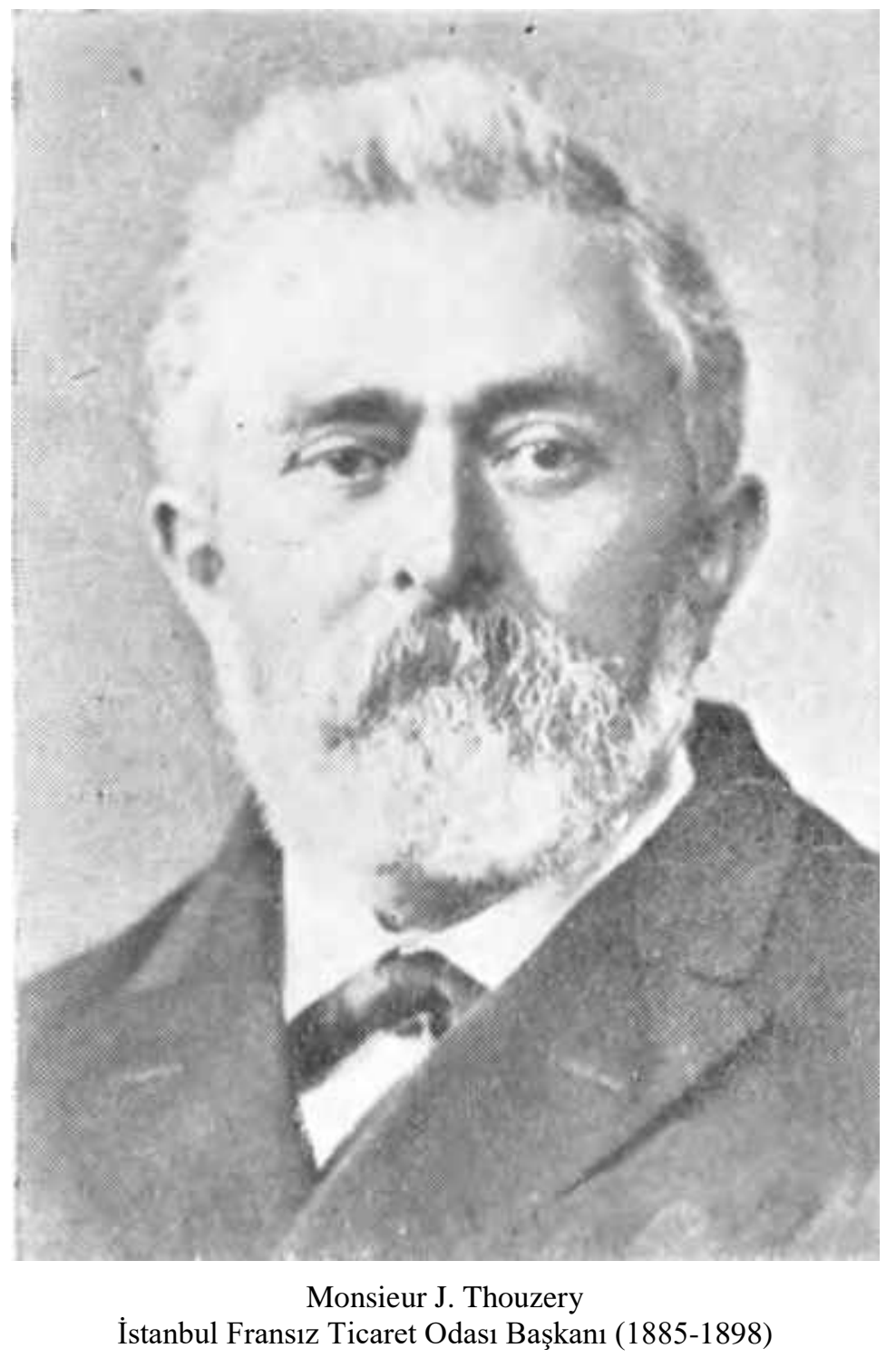

\footnotetext{
${ }^{20}$ Nizamnamenin maddeleri için bkz. ACCIM. MQ55/104, La Création d’une Chambre Française a Constantinople, Réunion des Notabes Commerçaints 6 octobre 1884.
} 
İstanbul Fransız Ticaret Odasının ilk nizamnamesi bu şekliyle kabul edildikten sonra, konsey üyeleri, odada büro hizmetleri için istihdam edilen idarecilerin belirlenmesi için 10 Ekim 1884 tarihinde üyeleri son kez bir daha toplanmaya davet etti. 10 Ekim'de Fransiz Konsolosluğunda yapılan toplantıda Fransız Konsolos Gazay onursal başkan olarak Ticaret Odasının başkanlığını J. Touzery’e tevcih etti. Touzery, görevde kaldığı 1898 yılına kadar geçen sürede odanın kurumsallaşmasında, üye ve abone sayılarının artmasında ve Fransız ticaret odalarının Levant kentlerinde kurulması ve yayılmasında önemli rol oynadı. J. Thouzery İstanbul Fransız Ticaret Odasının kurucu babası olarak zikredildi. 1884-1885 y1lı için büro müstahdemleri şu kişilerden oluştu: Başkan J. Thouzery, Sekreter Bertin, Veznedar Lemoine. ${ }^{21}$ Ancak bir süre sonra 1884 'te Odanın genel sekreterliğine Ernest Giraud seçildi. ${ }^{22}$ Thouzery yeni görevine hemen koyularak, yönetim kurulu üyelerinin mümkün olan en kısa sürede aidatlarını ödemeleri ve mümkün olduğunca fazla üye çekmek için her türlü çabayı göstermelerini talep etti. Böylelikle İstanbul Fransız Ticaret Odası kabul etmiş olduğu kuruluş nizamnamesiyle 10 Ekim 1884 tarihinde faaliyete geçmiș oldu. Oda başkanı J. Thouzery, Marsilya Ticaret Odası başkanına gönderdiği 27 Ekim 1884 tarihli mektubunda İstanbul Ticaret Odasının 10 Ekim itibarıyla işlemeye başladığını, ayrıca odanın İstanbul ile ilgili yararlı olabilecek her türlü malumatı sunmak için hizmette olduğu bildirdi. Benzer şekilde Marsilya Ticaret Odasından malumat talep edilmesi durumunda karşılanmasını ümit ettiklerini, bu suretle Marsilya ile İstanbul arasında mevcut olan ilişkilerin daha aktif ve güvenli hâle geleceğini belirtti. ${ }^{23}$ Oda meclisinin kabul ettiğgi 1884 nizamnamesi 22 Şubat 1888 tarihinde bazı küçük değişikliklerle yeniden tanzim edildi. ${ }^{24}$

Ticaret odasının merkez komitesi üyeleri de hızla değişti ve İstanbul'un en seçkin tüccar, sanayici, nakliyatçı, vapur kumpanyaları acenteleri gibi müteşebbislerinden oluştu. Üyelerin önemli bir kısmı da Levantenlerden oluşmaktaydı. İstanbul Ticaret Odası üyelerinin bağlı bulundukları meslekler şöyleydi: ${ }^{25}$

\section{İstanbul Ticaret Odası Meclisi (Membres du Conseil) ve üyeleri}

\begin{tabular}{|l|l|}
\hline $\begin{array}{l}\text { Başkan } \\
\text { Yardımcıları }\end{array}$ & Unvan ve meslekleri \\
\hline M. A. Gazay & Onursal Başkan, Fransız genel konsolosu \\
\hline M. J. Thouzery & Başkan, Mekanisyen ve İnşaatçı, Pancaldi 93. Çar Sokak \\
\hline Ernest Giraud & $\begin{array}{l}\text { Sekreter, Exploitation de la Société des Quais, Docks et Entrepôts } \\
\text { Şirketi Müdürü, Galata Ticaret Han }\end{array}$ \\
\hline Lemoin & Veznedar, Crédit Lyonnais Müdürü, Galata \\
\hline Meclis Üyeleri & Meslekleri \\
\hline Réne Boudouy & Banker, Galata Agopian Han'da \\
\hline Commandant L. Berger & Osmanlı Borçları Konseyi Başkanı (Düyun-1 Umumiye Başkanı) \\
\hline Emile Dumas & Hırdavatçı saraççı. Galata'da Çeşme 4. Sokak’ta \\
\hline Charles Garnier & Société des Phares de l’Empire Ottoman’da Mühendis, Pera, Ensiz 4. Sokak. \\
\hline Félix Granet & Société des Quais, Docks et Entrepots de Costantinople, yöneticisi. Galata \\
\hline J. Martin des Pallieres & Mesajeri Maritim Acentesi, Galata, Fransız Sitesi. \\
\hline Sylvain Mille & Fonciere Sigorta Şirketi, acentesi, Galata Bereket Han 10. \\
\hline Emile Monnier & Komisyoner, Sorumlu, Galata Zincirli Han \\
\hline Leon Sellie & Su Şirketi (La Compagnie des Eaux) Müdürü, Galata. \\
\hline Gasparin Van & Bon Marché Yöneticisi. Pera Büyük Yol \\
\hline
\end{tabular}

${ }^{21}$ ACCIM. MQ55/104, La Création d'une Chambre Française a Constantinople, Séance du 10 Octobre 1884, Réunion du conseil

${ }^{22}$ İBB. Atatürk Kitaplı̆̆ı, BEL(YD) 03093, Notice Historique sur la Chambre de Commerce Française d'Istanbul 1885-1935, İstanbul 1936, s. 1.

${ }^{23}$ ACCIM. MQ55/104, J. Thouzery'den (Marsilya) Ticaret Odası Başkanı'na, 27 Ekim 1884.

${ }^{24}$ Notice Historique sur la Chambre de Commerce Française d'Istanbul, s. 2.

${ }^{25}$ Chambre de commerce française de Constantinople, 10. Année, No: 117, 31 Septembre 1896, Constantinople 1896, s. 1. 
Oda ve oda üyelerinin dava ve anlaşmazlıklarına bakmak için A. Bardaut, César Bonnet, Simon Dahdah, Edouard Mille, Alexandre Reboul ve Octava Giraud adlarında 6 danışman avukatı da bulunmaktaydı. Odanın İstanbul'daki faaliyetleri hızla artınca, meclis üyelerinin sayıları da zaman içerisinde 13'ten 16'ya yükseldi. ${ }^{26}$ Aynı zamanda çevre kentlerde bulunan tüccarların istek ve beklentilerine daha hızlı ve kolay cevap vermek ve odanın yükünü hafifletmek maksadıyla İstanbul'a hem civar şehirlerde Çanakkale ve Bursa'da birer şube açıldı. Odanın Çanakkale ve Bursa'daki üyeleri şu şekildeydi: ${ }^{27}$

Çanakkale Fransız Ticaret Odası onursal başkanı Fransız Viskonsolusu M. C. Cabanel, Başkan ise Fraissinet Kumpanyası Çanakkale acentesi D. H. Georgiadés’ti. Meclis üyeleri Amédée Battus, Çanakkale’de Astyra Madenleri Müdürü; Gustave Battus, ziraatçi ve tüccar; Abraham Capsuto, Paquet Kumpanyası Acentesi; Bohor Capsuto, komisyoncu; Henri Kieger, komisyoncu; A. Paraskevaidis ise tüccar idi. Ticaret odaları, başta vapur nakliyat kumpanyaları acenteleri olmak üzere tüccar, komisyoncu, madenci gibi çok sayıda meslekten başkan ve meclis üyesine sahipti. Bu yapı birçok farklı mesleği ortak bir platformda toplayarak Osmanlı'daki Fransız yatırımcıların kaynaşmasını ve farklı sahalarda yatırım yapmasını teşvik etmekteydi.

Bursa Fransız Ticaret Odası onursal başkanı olarak Fransız viskonsolos M. L. Lacome; Başkan MM. Eugéne Porier, iplikçi, komisyonculuk mesleğiyle iştigal eden Alexadre Brotte ise hem sekreter hem de veznedardı. Odanın meclis üyeleri Tütün Rejisi Müdürü (La Regie des Tabacs) Richard Battus, ipekböceği yetiştiriciliği yapan ve mesleki eğitim veren Thomas Blanchet, komisyoncu Ernest Débétaz, iplikçi Louis Gamet, ecza ve marketçilikle iştigal eden Claud Lacaze'den oluşmaktaydı.

İstanbul ve yakın vilayetlerde ticaret odalarının kurulmasının hemen akabinde 1893 yılında imparatorluğun İstanbul'dan sonra en önemli liman kenti olan İzmir'de de Fransız Ticaret Odası açıldı ve 6 kişilik meclisiyle aktif olarak faaliyetlerine başladı. ${ }^{28}$ Çanakkale ve Bursa'daki odalar İstanbul Fransız Ticaret Odasının şubesi ve yardımcısı gibi hareket ederken, İzmir Fransız Ticaret Odası kendine özgü gazete çıkarmakta ve müstakil bir oda hüviyetinde hareket etmekteydi. Odanın Bulletin Mensuel de la Chambre de Commerce Française de Smyrne adlı aylık yayın yapan gazetesi 28 Şubat 1893 yılından itibaren yayımlanmaya başladı. ${ }^{29}$ İzmir Ticaret Odasının başkanı ise Fransız Vapur Nakliyat Kumpanyası olan Mesajeri Maritim'in İzmir acentesi Charles Salzani, veznedarı G. Trost, Arthur Bon ise sekreteri idi. ${ }^{30}$ İzmir Ticaret Odası, yapısı itibarıyla İstanbul'dakine benzer şekilde idare edilmekteydi. İzmir'deki odanın üye sayısı zaman içerisinde 120 'ye yükseldi, yıllık geliri ise 5.500 frang1 buluyordu. ${ }^{31}$ İstanbul Ticaret Odasının kuruluşu ve İstanbul'a hemcivar önemli mahallerde şubelerinin açılması, deniz nakliyat şirketlerinden, tütün rejisine, sanayicilerden tüccarlara ve komisyonculara kadar muhtelif alanlarda faaliyetlerde bulunan müteşebbislerin daha örgütlü ve düzenli münasebette bulunmalarına olanak tanıdı. Böylelikle Ticaret Odası, Fransız menfaatleriyle uyumlu grupları tek çatı altında toplayarak Fransız sermayesinin Osmanlı coğrafyasında gelişmesi ve yayılmasında önemli bir misyon yüklenmiş oldu.

Ticaret Odası kurulduktan kısa süre sonra birçok sahada etkin faaliyetler göstermeye başladı. Ticaret sergileri ve müzelerinin yapılmasını organize edecek, bunun için Fransa'daki

\footnotetext{
${ }^{26}$ Chambre de commerce française de Constantinople, 26. Année, No: 309, 31 Decembre 1912.

${ }^{27}$ Chambre de commerce française de Constantinople, 10. Année, No: 117, 31 Septembre 1896, Constantinople 1896, s. 24.

${ }^{28}$ ACCIM. MQ 55/104, Rapport Commercieux des Agents Diplomatiques et Consulaires de France, Année 1895, N. 271, Turquie D’Asie Mouvement Commercial de Smyrne, Pour l'année 1893.

${ }^{29}$ Bulletin Mensuel de la Chambre de Commerce Française de Symrne, 1. Année, N. 2, 28 Fevrier 1893.

30 AFL. 1997002 4473, Compagnie de Messageries Maritimes Agence de Smyrne, Rapport General de Service Exercice 1880, 1906, Chapitre 1, Personnel; Bulletin Mensuel de la Chambre de Commerce Française de Symrne, 1. Année, N. 2, 28 Fevrier 1893.

${ }^{31}$ Koraltürk, Türkiye'de Ticaret ve Sanayi Odalarl, s. 25.
} 
ticaret odalarından yardım alacaktı. ${ }^{32}$ Paris, Le Havre, Lyon ve Marsilya'daki ticaret odalarından yabancı ülkelerdeki ticari organizasyonlar için her yıl düzenli olarak ödenek aktarılmaktaydı. Fransız Ticaret Odası üyelerinin aidatları ve bu üyelerden gelen yardımların yanı sıra Fransız hükümetinden düzenli olarak yardım almaktaydı. Yabancı ülkelerde bulunan ticaret odalarının İngiltere, Almanya, Rusya ve Avusturya gibi devletlerin yabancı ülkelerdeki ticaret odalarıyla rekabet edebilmesi için Fransız ticaret odalarına 1885 y1lında 25.000, 1886'da $30.000,1887$ 'de $50.000,1888$ 'de $30.000,1889-90$ ve 91 'de $30.000,1892$ 'de ise 40.000 frank sübvansiyon verilmiştir. Y1llk olarak tahsis edilen bu sübvansiyonlardan İstanbul Ticaret Odasının payına düşen ise 3.000 frank idi. İstanbul Ticaret Odası Başkanı, Levant ticari rekabetinin ana merkezi olan İstanbul için tahsis edilen sübvansiyonu oldukça yetersiz bulmaktaydı. Başkanın bu isteği Fransız hükümeti nezdinde kabul görmüş olacak ki zaman içerisinde bu miktarın 7.000 franga kadar yükseldiği tespit edilmektedir. İstanbul Ticaret Odasının yıllık ortalama geliri ise 20.000 frank civarındayd.$^{33}$

Ticaret Odasının hazırladığı rapora göre İtalyanlar, Avusturyalılar ve Yunanların İstanbul'daki ticaret odalarına tahsis ettikleri sübvansiyon Fransızlara göre oldukça yüksekti. İtalyanlar sadece 1888 yılında yurt dışında bulunan ticaret odalarına 165.000 frank sübvansiyon verilmiştir. ${ }^{34}$ Ticaret Odasının en önemli faaliyetlerinden biri de hiç şüphesiz, Türk-Fransız ticaret ilişkilerinde ve Fransız tüccar ve yatırımcıların Levant ve Karadeniz liman kentleri ve hinterlandına dağılmaları ve bunların her türlü organizasyon ve münasebetlerinde belirleyici bir misyon yüklenmesiydi. Oda meclisi, dış ticaretle ilgili her türlü mevzuat ve karar hakkında Fransız hükümetine görüş bildirir, Fransız tüccarların menfaatlerini sınırlayan ya da ihlal eden hususlar hakkında Fransız hükümetini uyarırlardı. Mesela, Mesajeri, Fraissinet, Paquet, Fabre gibi Fransız deniz nakliyat kumpanyalarına ait vapurların bazı eşya türlerine ait navlun tarifelerinin düşürülmesi, Fransız posta şirketlerinin eşya naklinde özel tarife uygulanmasına dair oda tarafından dile getirilen talepler, Fransız hükümeti tarafından dikkate alınmıştı. ${ }^{35}$

İstanbul Fransız Ticaret Odası hızla geliştirdiği yerel ve uluslararası münasebetleri sayesinde gerek Avrupa ve diğer muhtelif ülkelerdeki ve gerekse Osmanlı coğrafyasında bulunan ticaret odaları bünyesindeki Fransız ve Fransız tabiiyetinde bulunan sanayici, tüccar ve tüm müteşebbislerin talep ve beklentilerine vâkıf olduğu için Türk-Fransız ticaret anlaşmalarının ihtivasının oluşturulmasında Fransız diplomatlara ve hükümetine ayrıntılı malumatlar sunmaktaydı. Hatta anlaşmaların içeriğinin belirlenmesinde belirleyici özelliğe sahip idi. Odanın bir diğer faaliyeti arasında da Fransız ticaretinin teşviki ve geliştirilmesi için her yıl bir miktar müteşebbis ruhlu Fransız gencinin Osmanlı Devleti'ndeki ticarethanelerde istihdamının sağlanmasında da aracı olmasıydı. ${ }^{36}$

Osmanlı Devleti ve Fransa arasında 29 Nisan 1861'de yapılan ve çeşitli değişikliklerle 1869'da tanzim edilen ${ }^{37}$ ve 1890 yılına kadar yürürlükte kalan Türk-Fransız ticaret anlaşmasını yenileme girişimi başarısızlıkla sonuçlanınca Fransız Ticaret Odası teşebbüslerde bulunarak bu anlaşmanın süresini en azından 2 yıl daha uzatmaya muvaffak olmuştu. 19. yüzyılda imzalanan Türk-Fransız ticaret anlaşmalarının temel ihtivası Balta Limanı Anlaşması (16 Ağustos 1838) ile İngilizlere tanınan hakların 25 Kasım 1838 'de Fransızlara tanınmasından oluşmaktadır. Bundan sonra ise peyderpey gerçekleşen ikili anlaşmalar da bu anlaşmanın daha da genişletilmesinden ibarettir. ${ }^{38}$ Fransızlara verilen Ancak Ticaret Odası başkanı Thouzery,

\footnotetext{
${ }^{32}$ ACCIM. MQ. 55/104, Création d’un Musée Commercial Français a Constantinople.

${ }^{33}$ Koraltürk, Türkiye'de Ticaret ve Sanayi Odaları, s. 24.

${ }^{34}$ Le Journal des Chambre de Commerce et d’Industrie, No 1., 12. Année, Paris, 10 Janvier 1893, s. 11.

${ }^{35}$ Toprak, "Osmanlı'da Ecnebi Ticaret Odaları", s. 4; Öndeş, Vapur Donatanlarl ve Acenteleri Tarihi, s. 145.

${ }^{36}$ Koraltürk, Türkiye'de Ticaret ve Sanayi Odalarl, s. 23.

37 ACCIM, MQ55/104, Tarım Ticaret ve Çalışma Bakanlığı, Paris 28 Ocak 1869; Muahedat Mecmuası, I., TTK, Ankara 2008, s. 44-45.

${ }^{38} 25$ Kasım 1838 anlaşması için bakınız. ACCIM. MQ, 55/103, Ambassade de France pres la Port Ottomane, Arreté concernant la Caravane, 24 Fevrier 1823.
} 
Fransız Ticaret Bakanı N. Girard'a gönderdiği raporunda adı geçen anlaşmanın muhakkak yenilenmesi için kısaca şunları bildirmişti: Sayın bakanımız Fransa ile Türkiye arasında imzalanan anlaşmanın sona ermemesi için Türkiye üzerindeki tüm nüfuzunuzu kullanmanızı talep ediyoruz. Türkiye Fransa için oldukça değerli bir pazardır. Osmanlı Imparatorluğu endüstriden yoksun olduğu için Fransa'ya hammadde tedarik etmektedir. Fransa ise bu pazara yıllık ortalama 60 milyon frangın üzerinde endüstriyel ürün satmaktadır. ${ }^{39}$

Ticaret Odasının bir başka görevi de Fransızları Karadeniz ve Levant Ticareti hakkında istatistikler tutarak, Fransızların Osmanlı coğrafyasında rekabet hâlinde olduğu diğer yabancı ülkelerin faaliyetleri Fransız pazarlarının oluşması ve tahkimi için detaylı araştırmalar yaparak veriler ve projeler sunmak ve hükümet kanallarını yönlendirmekti. ${ }^{40}$ Odanın bunun gibi muhtelif sahalarda çok çeşitli faaliyetleri söz konusuydu. Oda kurulur kurulmaz öncelikli olarak olabildiğince hızlı bir şekilde Osmanlı coğrafyasında bulunan Fransız ve Fransız tebaası, tüccar ve müteşebbislere ulaşarak onları aktif ya da pasif olarak üye yapmaya gayret gösterdi.

Odanın kısa sürede Osmanlı dâhilinden özellikle liman kentlerinden ve Osmanlı haricinden çok sayıda üyesi oldu. Yerel ve uluslararası bağları hızlı bir şekilde genişledi. 1887 yılında odanın il meclisinde 1 başkan, 1 sekreter, 1 veznedar ve 8 vekil, İstanbul'dan 52 aktif üye (Membres Actifs), Avrupa'nın muhtelif kentlerinden 86 tali üyesi (Membres Adherents) bulunmaktayd. ${ }^{41}$ Asil üyeler Fransız uyruğundan olmakla beraber idare meclisi bunlar arasında yapılan seçim ile oluşturulurdu. Tali üyeler, çalışmayan Fransızlardan ve Fransa'da veya Fransa haricinde bulunan, yani odanın kapsamı dışında kalan büyük ve küçük ölçekli şirketler, ticaret evleri ile tüzel kişilerden oluşmaktaydı. Bu şirketler ve kişiler odanın hizmet ve Yay.ndan yararlanıyor ve odaya mali yardımda bulunuyorlardı. Tali üyeler yönetimin belirlenmesinde oy sahibi değildiler. Asil ve tali üyelerin dışında fahri ve muhabir üyeler de vardı. Muhabir üyeler bulundukları yerlere dair ticari ve iktisadi konularda malumatlar verirdi. ${ }^{42}$

1896 y1lında odanın il meclisinde 1 başkan, 14 vekil ve İstanbul'dan 128 aktif üye ile birlikte toplamda 142; Çanakkale ve Bursa'daki şubelerinden 8'er olmak üzere 16 meclis üyesi bulunmaktaydı. Bunun yanında Avrupa'dan ticaret evleri ve şirketleri, sendika odaları ve muhtelif bölgelerdeki ticaret odalarından olmak üzere 747 üye, ayrıca Kıbrıs, Anadolu, Malta, Bulgaristan, Romanya, Sırbistan, İran, Yunanistan ve Rusya'dan da düzenli olarak yazıştığı 78 üyesi vardı. Odaya önemli hizmetlerde bulunan ya da önemli miktarda parasal yardım yapanlar fahri üye hakkı kazanıyordu. ${ }^{43}$ Tüm bunlar göz önünde bulundurulduğunda odanın toplam üye sayısı 1896 yılında 990'a yükselmiştir. ${ }^{44}$ Bu say1 1900 yılında $1001,{ }^{45} 1912$ yılında ise 1070'e yükselmiştir. ${ }^{46}$ Oda meclisi her türlü ticari ve iktisadi meselelere ilişkin her y1l bini aşkın mektup alıyor ve bunlara yanıt veriyordu. Birçok Fransız şirket, fabrika, ticarethane sahibi tali üye sıfatıyla odaya üye oldukları için oda yönetimi, bunlara Osmanlı'daki müşterilerinin itibar derecelerine ve faaliyetlerine dair ayrıntılı malumatlar verir ve temsilciler sağlardı. ${ }^{47}$

${ }^{39}$ ACCIM. 55/104, 13 Fevrier 1890, Monsieur Girard, President du Conseil Ministre du Commerce de l'Industrie et des Colonies Paris.

${ }^{40}$ ACCIM. MQ55/104, Chambre de Commerce Française de Constantinople, N. 3, Constantinople le 15 Juin 1887, Cambre de Commerce Française de Constantinople a Mansieur le President de la Cambre de Commerce de (Marseille), 27 Octobre 1884.

${ }^{41}$ Chambre de Commerce Français de Constantinople, 1. Année, No. 7, 20 Octobre 1887, s. 1-2.

${ }^{42}$ Koraltürk, Türkiye'de Ticaret ve Sanayi Odalarl, s. 23.

${ }^{43}$ Toprak, "Osmanlı'da Ecnebi Ticaret Odaları", s. 4.

${ }^{44}$ Chambre de commerce française de Constantinople, 10. Année, No: 117, 31 Septembre 1896, Constantinople 1896, s. 23.

${ }^{45}$ Chambre de commerce française de Constantinople, 13. Année, No: 117, 31 Mars 1900, Constantinople 1900, s. XL.

${ }^{46}$ Chambre de commerce française de Constantinople, 26. Année, No: 309, 31 Décembre 1912, Constantinople 1912, S. LIV.

${ }^{47}$ Koraltürk, Türkiye'de Ticaret ve Sanayi Odalarl, s. 23. 
Üyelerinin her türlü ticari davalarına bakabilmek için ayrıca odanın A. Bardant, César Bonnet, Simon Dahdah, Edouard Mille adlarında dört kişiden oluşan tecrübeli avukatları bulunmaktaydı. ${ }^{48}$ Üyelerin sayısı ve davalardaki yoğunluğun artmasından dolayı 1908'de avukatların sayısı 9'a yükseldi. ${ }^{49}$ Avukatlık hizmeti oda üyelerinin yerel müteşebbislerle yaşadıkları davaların çoğunu kazanmasında önemli bir rol oynadılar. Bu ise son dönemlerde hukuki manada gelişen ve değişen ticaret kanun ve usullerine vâkıf olmayan yerel tüccarların odaya üye Fransız ve tebaası müteşebbislerin karşısında çoğu davaları kaybetmelerine sebebiyet vererek, yabancı tüccarın davalarda elini güçlendirdi. ${ }^{50}$

İstanbul Fransız Ticaret Odasının üyelerine sağladığı firsatlar ve faydalara dair vaatleri oldukça fazla ve yararlı idi. Oda tarafından 1887 'den itibaren aylık olarak yayımlanan gazetede kurumun üyelerine sunduğu avantajlar şu başlıklar altında sıralanmıştır:

\begin{abstract}
Metropolün sanayici ve tüccarları, Levant ile ticari ilişkilerde ticari itibarla kolay bir şekilde pazar bulmak istiyorlarsa, üye ve ticaret odamızın bir parçası olarak büyük bir avantaja sahiptirler.

Her bir üyemiz istediği kadar bağıșta bulunmakta özgür olmakla beraber, sembolik bir katkıyla, yıllık asgari olarak 10 frank üyelik bedeli ödemekle mükelleftirler. Bunun karşılığında üyeler düzenli olarak Le Bulletin Mensuel adındaki gazeteyi alırlar. Bu gazete tüm Levant ticareti hakkında okuyucularına ayrıntılı ve faydalı malumat sunan bir hacme sahiptir. Derginin her sayısında şirketlerin isimleri ve şubelerine dair alanında uzmanlaşan detaylı makaleler ve mükemmel reklamlar yer almaktadır.

Üyelerimize sadece İstanbul'daki müşteriler için değil, yazışmalarımızla Levant'ın belli başlı şehirleri hakkında da ücretsiz ve tutarlı bilgiler veririz. Aynı zamanda onlara temsilciler sağlar, iletişim adreslerini temin eder, her türlü bilgi ve tavsiyelerde bulunuruz. Üyelerimizin anlaşmazlık, iflas gibi ticari konularda davalarını düzeltmek için çalışır ve avukatlarımızla onları temsil ederiz. Yasal olarak fabrika ürünlerinin markalaşmasına/tescillenmesine yardımcı oluruz. Sonuç olarak üyelerimize her zaman faydalı olmaya ve iş tecrübelerimizden onları yararlanmaya hazır hâle getirmeye gayret gösteririz.

Şarkta ticari ve endüstriyel faaliyetlerle ilgilenen müteşebbis üyelerimizi Fransa'daki tüm tüccarlar ve sanayiciler kuşkusuz destekleyeceklerdir. Keza bu ülkede acil çıkarları olmayan büyük ticaret evleri, finansal ve endüstriyel kuruluşlara vatanseverlikle yardım etmeye çalışırız. Levant'ın tüm pazarlarında ulusal (Fransız) ticaretin çıkarlarını korumak için yaptığımız çalışmalarla onları teşvik ederiz. ${ }^{51}$
\end{abstract}

\footnotetext{
${ }^{48}$ Chambre de commerce française de Constantinople, 10. Année, No: 117, 31 Septembre 1896, Constantinople 1896, s. 1.

${ }^{49}$ Chambre de commerce française de Constantinople, 12. Y11, No: 261, 31 Decembre 1908, Constantinople 1908, s. 14.

${ }^{50}$ Ahmet Lûtfi Efendi, Vak'anüvis Ahmet Lûtfi Efendi Tarihi, (Haz. Yücel Demirel), 1-7-8, Tarih Vakfi Yapı Kredi Yay., İstanbul 1999, s. 1051-1052.

${ }^{51}$ Cambre de Commerce Française de Constantinople, 20. Année, 28 Fevrier 1907, N. 239, Imprimerie Française, Constantinople 1907, p. II.
} 


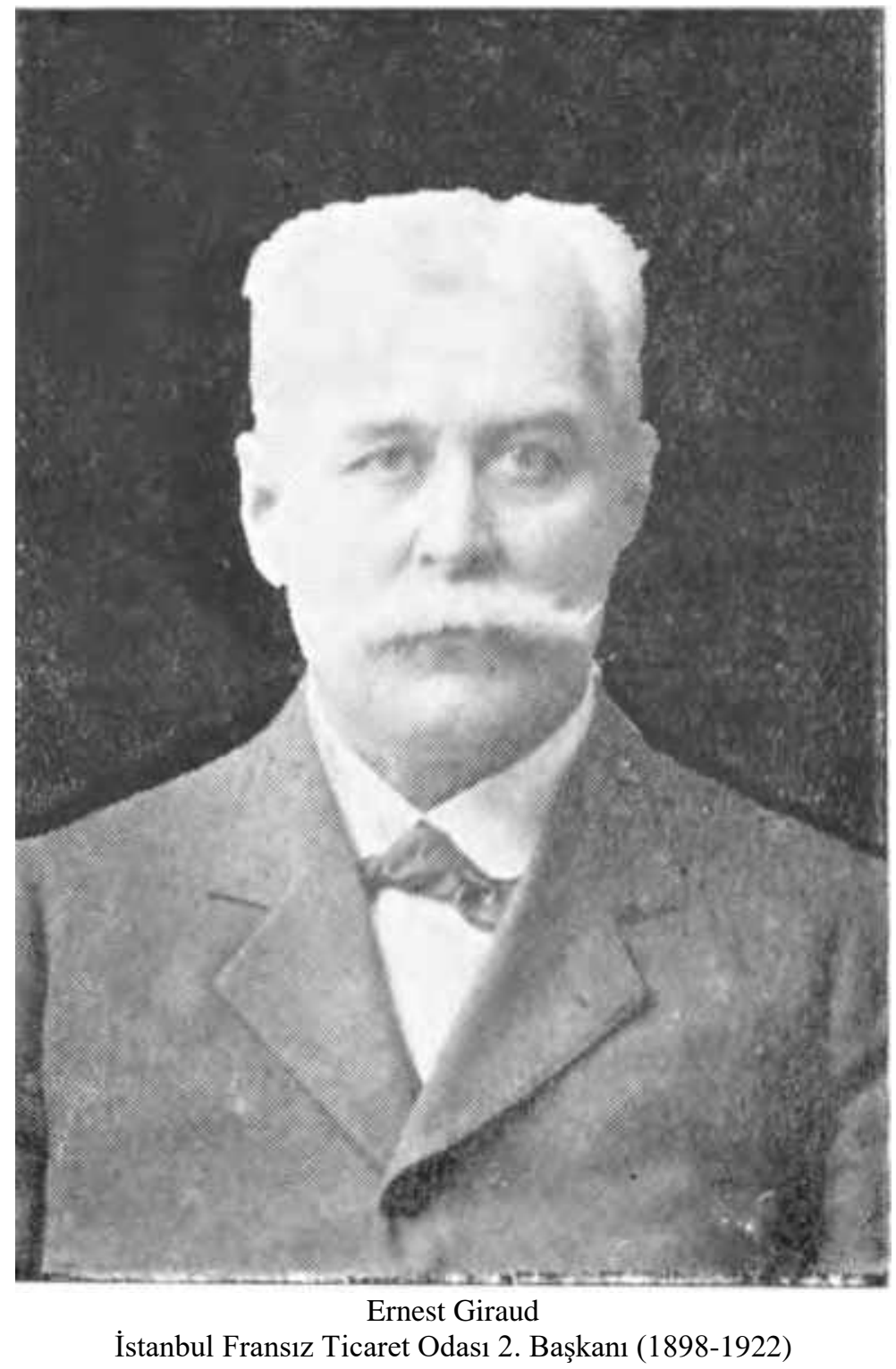

Fransız sermayesinin ve menfaatlerinin Levant ve Karadeniz limanları ve hinterlandında yayılması ve bunların muntazam bir yapı içerisinde aralarında sık1 münasebetler tesis edilmesinde odanın çıkarmış olduğu gazete önemli bir vasıta oldu. Ticaret odası Revue Commerciale du Levant Chambre de Commerce Française de Constantinople adıla 1887 yılı itibarıyla ayda bir defa olarak yayım hayatına başladı. ${ }^{52}$ Gazetenin ilk sayıları Meclis genel sekreteri olan M. E. Giraud tarafindan kaleme alınd1. Basımı ise Galata'da Kuyumcular Hanı'nda yapılmaktaydı. ${ }^{53}$ Aynı zamanda Galata'da bulunan Fransız Antrepo, Dok ve Rıhtım Şirketi'nin (Exploitation de la Société des Quais, Docks et Entrepôts) müdürüydü. ${ }^{54}$ Giraud bu gazete yazarlığından ve editörlügünden edindiği tecrübe sayesinde Ticaret Odası nezdinde kısa sürede değerli, vazgeçilmez ve saygın bir konuma yükseldi. J. Thouzery'den sonra 1898 yılında odanın başkanlığına seçildi ve 1922 yılına kadar bu görevinde kaldı. ${ }^{55}$

\footnotetext{
52 Chambre de Commerce Français de Constantinople, 1. Année, Constantinople, 20 Octobre 1887, No. 7, s. 1-2.

${ }^{53}$ Notice Historique sur la Chambre de Commerce Française d'Istanbul, s. 3.

${ }^{54}$ Chambre de commerce française de Constantinople, 10. Année, No: 117, 31 Septembre 1896, Constantinople 1896, s.1.

${ }^{55}$ Notice Historique sur la Chambre de Commerce Française d'Istanbul, s. 3.
} 
Başlı başına müstakil olarak araştırmalara konu olabilecek bu mecmuada tarım, ticaret, ziraat, iktisat, denizcilik, posta taşımacılığı hakkında ayrıntılı bilgiler verilmekteydi. Özellikle Balkanlar'dan Odesa, St. Petersburg ve Kafkasya’ya, Samsun, Giresun, Trabzon, Erzurum, Kayseri, Konya, Adana, İzmir, Diyarbakır gibi Anadolu dâhilindeki çoğu vilayetlerden Kıbrıs, Syra, Trablus, Beyrut ve Kudüs'e kadar muhtelif kentlerde bulunan muhabir oda üyelerinden gelen mektuplar, raporlar önemli malumatlar içermekteydi. ${ }^{56} \mathrm{Bu}$ muhabirler genellikle Fransız konsolosları ve yardımcıları, tercümanları, Osmanlı bankası, Düyun-1 Umumiye İdaresi ve Reji şirketi memurları ve mühim tüccar ve müteşebbislerden oluşmaktaydı. ${ }^{57}$

1896 yılından itibaren mecmuanın çoğu sayısında Osmanlı vilayetlerinde ticarete konu olan bir ürün ayrıntılı olarak işlenmekte, derginin ilk sayfası o sayıya tahsis edilen ürünle başlamaktaydı. Örneğin 1896 yılı Aralık sayısında tereyağı ve yağlar, ${ }^{58} 1897$ yılı Ağustos sayısında alkol, ${ }^{59} 1898$ yılı Eylül sayısında peynir, ${ }^{60} 1899$ yılı Ekim sayısında fes, ${ }^{61} 1900$ yılı Mart sayısı eldiven, 1901 yılı Şubat sayısı arpa, madenler, kıyafet gibi ürünler hakkında ayrıntılı bilgiler verilmekteydi. Bu tarihten sonra ise neredeyse her sayısının kapak kısmında ticarete konu olan bir ürüne dair zirai, ekonomik, tarihsel ve sosyokültürel anlamda detaylı bilgilere değinilmekteydi. 1902 yılı sayılarında müzik aletleri, makine, enstrüman, parfüm vs., ${ }^{62} 1903$ 'te çikolata, kakao, şarap, pamuk, bal, vs., ${ }^{63} 1904$ 'te ip makinası, iplik, makas, bone, likör vs., ${ }^{64}$ 1905 'te kenevir, biber, porselen, bardak, gümüşlük ${ }^{65}$ vs., 1906'da patates, un, yumurta, çivit, deri vs. gibi ürünler gazetenin ilk sayfasında ele alınarak incelenmekteydi. ${ }^{66}$

Osmanlı coğrafyasındaki ticaret, ziraat, madencilik ve iktisada konu olan bu ürünlere gazetenin çoğu sayılarında yer verilerek ülkenin potansiyel zenginlikleri Batılı tüccar ve müteşebbislere tanıtılmakta, böylelikle bu gruplar için ticarete ve yatırıma dönüşebilecek ilgi çekici, cezbedici tüm ürünler Fransız ekonomisine dâhil olabilmekteydi. Ticaret odasının 10. yılı kuruluş yıl dönümünde Osmanlı coğrafyasına dair verilen istatistiki bilgilerin 140 limanı, 49 ticaret merkezini kucakladığ ve uğrak noktaları gibi bilgiler içerdiğini ifade etmekteydi. İstatistiki raporlar sadece tüm Türkiye'yi değil aynı zamanda Kıbrıs, Bulgaristan, Mısır, Romanya, Sırbistan, Rus Avrupası ve İran'1 ve tüm Levant bilgilerini içermektedir. Deniz nakliyatını desteklemek için ise tüm Osmanlı limanlarındaki hatta en küçük iskelelerdeki vapur hareket saatleri ve tarifeleri, buna ek olarak Osmanlı dâhilindeki demiryolu hareketliliğine dair bilgiler de detaylı bir şekilde belirtilmiştir. ${ }^{67}$

Ticaret odasının 10. kuruluş yılına tesadüf eden Eylül 1894 sayısında odanın bu güne kadar yapmış olduğu faaliyetleri hakkında özetle şunlardan söz edilmekteydi:

\footnotetext{
${ }^{56}$ Chambre de Commerce Français de Constantinople, 8. Année, No. 7, 30 Septembre 1894, s. 2.

${ }^{57}$ Koraltürk, Türkiye'de Ticaret ve Sanayi Odalarl, s. 24.

${ }^{58}$ Chambre de Commerce Français de Constantinople, 10. Année, No. 117, 31 Decembre 1896.

${ }^{59}$ Chambre de Commerce Français de Constantinople, 11. Année, No. 125, 31 Aout 1897.

${ }^{60}$ Chambre de Commerce Français de Constantinople, 12. Année, No. 138, 30 Septembre 1898.

${ }^{61}$ Chambre de Commerce Français de Constantinople, 13. Année, No. 151, 31 Octobre 1899.

${ }^{62}$ Chambre de Commerce Français de Constantinople, 16. Année, No. 189, 31 Decembre 1902; Chambre de Commerce Français de Constantinople, 15. Année, No. 178, 31 Janvier 1902; Chambre de Commerce Français de Constantinople, 16. Année, No. 184, 31 Juillet 1902.

${ }^{63}$ Chambre de Commerce Français de Constantinople, 16. Année, No. 190, 31 Janvier 1903; Chambre de Commerce Français de Constantinople, 17. Année, No. 193, 30 Avril 1903; Chambre de Commerce Français de Constantinople, 17. Année, No. 194, 31 Janvier 1903, Ayrıca diğer ürünler için aynı yılın diğer sayılarına bkz.

${ }^{64}$ Chambre de Commerce Français de Constantinople, 17. Année, No. 203, 29 Février 1904; Chambre de Commerce Français de Constantinople, 17. Année, No. 204, 31 Mars 1904. Ayrıca diğer ürünler için aynı yılın tüm sayılarına bkz.

${ }^{65}$ Chambre de Commerce Français de Constantinople, 18. Année, No. 216, 31 Mars 1905; Chambre de Commerce Français de Constantinople, 19. Année, No. 217, 31 Avril 1905, Ayrıca diğer ürünler için aynı yılın tüm sayılarına bkz.

${ }^{66}$ Chambre de Commerce Français de Constantinople, 20. Année, No. 230, 31 Mai 1906.

${ }^{67}$ Chambre de Commerce Français de Constantinople, 8. Année, No. 7, 30 Septembre 1894, s. 2.
} 
1884'te kurulan odamız 10 yıldan bu yana varlığını devam ettirmektedir. Faaliyet gösterdiğimiz süre boyunca metropol ticaretine bir an bile pes etmeksizin hizmette bulunduk. Bu süre zarfında daha iyi anlaşılabilseydik, daha fazla katkımız olabilirdi.

Fransa'da ikamet eden vatandaşlarımızın çoğu, ancak yanlış bir yatırıma ya da hadiseye maruz kaldıklarında bizleri tanıdılar. Eğer bizi daha önce tanımış olsalardı, bizi görmezden gelen tüccar ve müteşebbislerin sayılarının çok fazla olması şaşırtıcı olmazdı. Bunlar arasında bizi tanıyanların birçoğu dahi Doğu'da yatırımlarını geliştirmek için onlara sunduğumuz yardımı tam olarak nasıl kullanacaklarını bilmiyorlar. Müteşebbisler bizim kuruluşumuzu / kumpanyamızı basit bir şekilde hükümet tarafından ekonomiyi geliştirmek için kurulmuş ve birkaç frank karşılığında Levant tüccarları tarafından verilen raporlardan oluşan ücretsiz bilgi veren bir acente olarak düşünmektedir.

Yabancı ülkelerdeki Fransız ticaretinin emrindeki ticaret evlerinin kredileri hakkında verdiğimiz bilgiler kurumumuz tarafindan verilen hizmetlerin sadece bir bölümünü oluşturur. Biz ayrıca yatırımcılara yanlış hesapları işaret ederek hayal kırıklığından kaçınmak ve onların çıkarlarını güvenilir ellere teslim etmek için Türkiye'de uzun çalışma sürecince edindiğimiz deneyimi paylaşmaya istekliyiz. Bu nedenle vatandaşlarımızda bize sık sık danışmalarını ısrarla istiyoruz. Ticaret Odasına başvuranlar biliyorlar ki her zaman istekli bir şekilde ve gerçek bir memnuniyetle onlara cevap veriyoruz. Çok çalışmamızın ödülü kendimizi daha fazla tanıtmaktır. Ayrıca aylık bültenimizi okumanızı öneririz, bu sizin için oldukça faydalı olacaktır. ${ }^{68}$

Ticaret odası aynı zamanda Fransız ekonomisinin Osmanlı coğrafyasında gelişmesi için yararlı olabilecek araştırmacı, seyyah ve müteşebbisleri de üyelerine tanıtmaktaydı. Örneğin meslektaşları ve arkadaşları olarak söz ettikleri Vital Cuinet'in La Turqui d'Asie adlı eserinin Fransız yatırımcılar için harika bir kaynak olduğunu, hatta Cuinet'in bu kıymetli eserinin bizzat Sultan Abdülhamid'in Türkçeye tercümesi için talimat verdiğini, keza Cuinet'e İmparatorluk okullarında ders vermesi için yetki verdiği belirtilmekteydi. Odanın raporuna göre Cuinet'e bu çalışmasından dolayı Sultan tarafindan gümüş liyakat madalyası verilmiştir. Sultan Abdülhamid'in Fransız vatandaşı ve oda üyesi müteşebbislere vermiş olduğu nişanlar gazeteye konu olmuştur. Mühendis Louis Baudouy'a 4. Sınıf Osmaniye, porselen fabrikası müdür yardımcısı ve Beyrut-Şam Arabaları Şirketi direktörü L. Blanchet'ye 4. Sınıf Mecidiye, Manifatura fabrikası şefi M. Renard'a 4. Sınıf Mecidiye gibi birçok Fransız yatırımcıya Sultan tarafından nişan verilmiştir. Keza Chambre de Commerce Français de Constantinople adlı oda gazetesinin baş muharriri Ernest Giraud'a üçüncü dereceden Osmanlı nişanı verilmiştir. ${ }^{69}$

Chambre de Commerce Français de Constantinople adıyla yayın hayatını sürdüren Oda bülteni muhabirleri ve üyeleri sayesinde Yakın Doğu'dan Levant'a, Kıbrıs'tan Rodos, Yunanistan, Bulgaristan, Romanya ve Rusya'ya kadar 171 ayrı bölge hakkında ticaret, ziraat ve endüstri hakkında ayrıntılı bilgileri okuyucusuna sunmaya devam etti. Oda bülteni Osmanlı coğrafyasından Avrupa'ya kadar iktisadi yayınlar yapan gazeteler arasında önemli bir konuma yükseldi. 1889'da tiraj1 600 iken 1914'te 1800'e yükseldi. Ancak çoğu ecnebi matbuatında âdet olduğu gibi Fransız Ticaret Odası Gazetesi de zaman zaman siyasi konuları ele almasından dolayı muzır yayın statüsünde sansüre maruz kalmıştır. ${ }^{70} 6$ Mayıs 1893 tarihli Osmanlı resmî kaydında, bu gazeteler mevad-ı ticariye, sinaiye ve maliyeden bahs edip iş bu gazetelere bu hususta ruhsat verilmiş olduğu hâlde buna riayet etmeyerek aralık aralık havadis-i siyasiye derç etmekte ve hükümet-i seniyenin hukuk ve menfaati aleyhine dokunacak surette makalata kalklşmakta... oldukları belirtilmekteydi. ${ }^{71}$ Oda bülteni Matbuat Müdürlüğ̈̈ tarafından zaman zaman takibata ve sansüre maruz kalsa da kesintisiz bir şekilde yayın hayatına devam etti. 1912

\footnotetext{
${ }^{68}$ Chambre de Commerce Français de Constantinople, 8. Année, No. 7, 30 Septembre 1894, s. 2.

${ }^{69}$ BOA. Y. EE, 149/133, 29 Ekim 1899.

${ }^{70}$ BOA. BEO. 3007/225497, 5 Mart 1907; DH. MKT. 30/27, 6 May1s 1893.

${ }^{71}$ BOA. DH. MKT. 30/27, 6 Mayis 1893.
} 
yılında kuruluşunun 25. y1lına özgü 799 sayfadan oluşan özel bir yayınla jübilesini yaptı. Bültenin son sayıs1 30 Haziran 1914 'te yayımland. ${ }^{72}$

\section{Cumhuriyet Türkiyesinde Odanın Yapısı ve İşlevinin Değişmesi}

I. Dünya Savaşı esnasında Türk-Fransız ticaret ilişkileri koptuğu için Ticaret Odası kapandı ve odanın bülteni 54 ay boyunca yayımlanmadı. ${ }^{73}$ Mütarekeden sonra Fransız Ticaret Odası ilk firsatta yeniden açıldı. 17 Aralık 1918 'de Oda meclisi az sayıda üyesiyle yeniden toplandı ve 328 numaralı bülten 30 Nisan 1919'da yayımland1. Bunu düzensiz olarak altı adet yayımlanan gazete takip etti. 1920'den sonra ise her ay düzenli olarak yayın hayatına devam etti. Odanın yayın işleri savaş esnasında tahrip olan arşivleri yeniden restore etmek, bilgi fişlerini yeniden düzenlemek, eski yazışmaları toplamak ve sınırların değişmesinden kaynaklanan yeni ticari şartlara uyum sağlamak için yoğun bir çalışma içerisine girdi. Gazete $L a$ Revue Commerciale du Levant Chambre de Commerce Français de Constantinople, adıyla yayın hayatına 1930 yılına kadar devam etti. Bu tarihten sonra ise 1918 yılında M. Valery tarafından kurulmuş olan d'Information d'Orient adlı ticaret ve iktisat gazetesiyle birleşti ve yayın hayatını bu isimle sürdürdü. ${ }^{74}$

I. Dünya Savaşı'ndan sonra Ticaret Odasının yeniden açılışı ve ne şekilde işleyeceği, odanın statü ve tüzüğünün yeniden tespiti, hatta oda meclisinin ne şekilde toplanacağı önemli sorunlar arasındaydı. Zira savaş esnasında odanın meclis azaları ve aktif üyelerinin çoğunluğu Osmanlı coğrafyasını terk etmiş, Fransa'ya yerleşmişti. Ticaret odası şeklen de olsa birkaç üyesiyle 1918 'de savaş sonrası ilk toplantısını yapabilmişti. Bundan iki yıl sonra 24 Haziran 1920 tarihinde yapılan yeni toplantıda odanın yeni statüsü ve iç tüzüğünün belirlenmesine yönelik kararlar alındı. Ancak bunları kabul edecek ne bir meclis ne de başkan mevcuttu. Fransız Ticaret Bakanlığı ile münasebete geçilerek iş birliği içerisinde yeni ticaret ofisi açıldı. Ticaret Ofisinin üyesi M. Pesserau, meclis üyesi olarak seçildi ve odanın sekreteri olarak tayin edildi. 1925 y1lında ticari ataşe olana kadar bu görevinde kaldı. Yeni Türk Cumhuriyeti'nin Lozan Antlaşması'yla kapitülasyonları ve kabotajı lağvederek millî ve devletçi iktisadı benimsediği süreçte ${ }^{75}$ Türk ekonomisinin dizginleri tedricen yerli müteşebbislerin eline geçti. Fransız Ticaret Odası meclisinin Osmanlı döneminde olduğu gibi yeterince Fransız ve gayrimüslim meclis azası ve oda üyesi bulması imkânsız bir hâl aldığından oda tüzügünde bu yönde ilk köklü değişiklik 20 Mart 1924'te yapıldı. Yapılan en önemli değişiklik aktif üyeler başlı̆̆ında oldu. Buna göre aktif üyeler Türkiye'deki bir Fransız ticarethanesi, şubesi ya da Fransız kuruluşun acenteliğini yapan yabancılardan seçilebilecekti. Buradan kasıt şüphesiz bundan böyle Türk ve Müslüman müteşebbisler de odanın aktif üyesi olabilecekti.

1926'dan sonra odanın aktif üyeleri arasında Kâzım Fuat (Vakıf Han'da Bankacı, Ticaret Sorumlusu), Ali Nuri Bey (Galata' da Ali Nuri Kumpanyas1, Ticaret sorumlusu), ${ }^{76}$ Abbas Kâtip Bey (Kâtip Han'da Tüccar ve Manifaturac1) ${ }^{77}$ gibi birkaç Türk vatandaşına tesadüf edilmektedir. Cumhuriyet öncesi dönemde ise odanın aktif üyeleri arasında Türkler yer almamaktaydı. İstanbul Ticaret Odası her ne kadar genç Cumhuriyet hükümetinin politik duruş ve çekincelerine göre iç tüzük ve yapısında değişikliklere gitse de Cumhuriyet hükümeti kapitülasyon hukuku etrafında oluşan tüm müesseselerin ya lağvedilmesi ya da yeni Türkiye'nin ekonomik yapısı ile uyumlu hâle getirilmesine yönelik sert bir siyaset izlediğinden diğer Ecnebi Ticaret Odaları gibi Fransız Ticaret Odasının da kaderi Türk hükümetinin inisiyatifine göre

\footnotetext{
${ }^{72}$ Chambre de Commerce Français de Constantinople, 25. Année, No. 300, 31 Mars 1912, s. 367; Chambre de Commerce Français de Constantinople, 27. Année, No. 324, 31 Mars 1914.

${ }^{73}$ Notice Historique sur la Chambre de Commerce Française d'Istanbul, s. 6-7.

${ }^{74}$ Notice Historique sur la Chambre de Commerce Française d'Istanbul, s. 7.

${ }^{75}$ Lozan Barış Konferansı Tutanaklar Belgeler, (Çev. Seha L. Meray) I. Takım C. II, YKY, İstanbul 1993, s. 1-15.

${ }^{76}$ Chambre de Commerce Français de Constantinople, 36. Année, No. 407, Octobre 1929, Constantinople 1929, s. XII-XIII.

${ }^{77}$ Chambre de Commerce Français de Constantinople, 35. Année, No. 378, Janvier-Fevrier 1925, Imp. Française L. Mourkides, Rue Luledji Hendek 125, Constantinople 1925, s. XI.
} 
yeniden tespit edildi. ${ }^{78}$ İstanbul'da işgalci kuvvetlerin geri çekilmesinden sonra işgalci devletlerin İstanbul'daki kurumlarına karşı sert bir tutum sergilendi. Bu tutumun hukuki alt yapısı şüphesiz Lozan Anlaşması'nda elde edilen başarıdan kaynaklanmaktaydı. ${ }^{79}$

2 Mayıs 1925 tarihinde Mecliste alınan 655 sayılı karar gereği tüm ecnebi ziraat ve ticaret odalarının kapatılması kararlaştırıldı. 1943 yılında ise bu kanun 4355 sayılı kanunla daha da kapsamlı hâle getirildi. ${ }^{80}$ Bu bağlamda başta İtalyan ve Fransızlar olmak üzere Türkiye'de ticaret odaları bulunan tüm yabancı devletlerin elçiliklerine bu türden kurumların tümünün faaliyetlerine hemen son vermesine yönelik Türk Dışıişleri Bakanlığı delegesi Nusret Bey tarafından tebligat yapıldı. Karar alındıktan bir müddet sonra 14 Ağustos 1926 tarihli belgede Fransız Büyükelçisi Türk polis kuvvetlerinin Ticaret Odasına geldiği ve yürürlüğe konulan yasa gereği bundan sonra tüm ecnebi ticaret ve sanayi odalarının varlığının yasal olmadığ 1 ve ticaret odaların ticari rekabet konusunda Türkiye'deki ticaret odalariyla uygun olmayan nitelikte kuruluşlar olduğu ve bunların kendi ülkelerinin menfaatleri doğrultusunda faaliyet gösterdiği, Türk ticaret odaları ile rekabet hâlinde bulunduğu gibi birtakım nedenler dolayısıyla faaliyetlerini bir an önce sonlandırmalarına dair talimat verdiğini bildirdi. ${ }^{81}$

Ecnebi ticaret odaları hakkında TBMM'de alınan kararda ticaret odası sıfatı taşıyabilmek için şu şartların olması kabul edildi:

1. Yabancılar veya Türk vatandaşlarıyla bir arada teşkil olunacak kurumların ticaret odası unvanı kullanabilmesi için cemiyetin muamele ve kayıtlarının Ticaret Vekilliği tarafından her zaman teftiş ve denetime tabi tutulması.

2. Bu cemiyetlerin umumi kâtiplerinin Türk olması ve tayinlerinin Ticaret Vekilliği tarafından tasdik edilmiş bulunması.

3. Senelik faaliyetlerine dair her takvim yılı sonunda Ticaret Vekilliğine rapor vermeleri esas1 kabul edildi. ${ }^{82}$

Yabancı ticaret odaları bu ağır denetimler karşısında bir dönem faaliyetlerini sonlandırmak zorunda kaldılar. Ancak yabancı devlet temsilcileri bu konuda teşebbüste bulunmaya devam ettiler. Diğer yandan bu esnada Berlin'de Türk-Alman ticaret odas1, Marsilya'da Türk-Fransız ticaret odası, Atina'da Türk-Yunan ticaret odası olduğu ve yine Londra'da bir Türk-İngiliz ticaret odası kurulması teşebbüsünden dolayı mütekabiliyet esasına göre bunların varlıklarına hukuki bir şekil vermek gerektiği üzerine anlaşıldı. Nihayet mecliste bu kurumların yeni statüsü ve tanzimi için karar alındı. Manisa Milletvekili Faik Kurdoğlu yabanc1 ticaret odaları hakkında alınan bu kararı şu şekilde dile getirmekte ve tavsiyede bulunmaktaydı: 655 sayılı Kanun'da ticaret ve sanayi odaları unvanı altında teşekkül vücuda getirebilmek hakkını Ticaret Vekâleti verdiği ve yabancı ticaret odaları ise Ticaret Vekâleti tarafindan vücuda getirilmiş olmadiklart için cemiyet ve dernek olma yoluna başvurmuşlardır. Şimdi bunlar ticaret odası unvanin bir cemiyet olarak kullanabilsin ve Cemiyetler Kanunu'na tabi olarak Ticaret Vekâletinin murakabesi altında olsun. Bunların muamele ve kayıtları Ticaret Vekilliğince her zaman teftiş ve murakabe edilsin, bunda cidden bazı tecrübelere nazaran fayda vardir. ${ }^{83}$ Buna göre Kanun'un tespit ettiği “ticaret ve sanayi odası" tabiri, bundan böyle ticaret odası unvanı değil de cemiyet veya dernek adı altında Ticaret Vekâletinin denetimi altında

\footnotetext{
${ }^{78}$ Türk Hükûmeti'nin Karadeniz'deki Fransız şirketlerini sıkı denetim altına aldığı ABD Büyükelçisi Joseph Grew’un raporlarında da yer alıyor. Zonguldak'taki Fransız kömür şirketi Cumhuriyet döneminde bu baskıyı en fazla hissedenlerdendi. Hakan Güngör, “ABD Büyükelçisi Joseph C. Grew’un Karadeniz Seyahati ve Gözlemleri,” ODÜ SOBIAD, 8 (3), Kasim 2018, s. 583.

${ }^{79}$ Lozan Barış Konferansı Tutanaklar Belgeler, (Çev. Seha L. Meray)I. Takım C. II, YKY, İstanbul 1993, s. 1-15.

${ }^{80}$ TBMM Zabit Ceridesi, Devre VI, C. 30, İçtima 4, Yirmialtıncı inikat, 11. 1. 1943, s. 127; Kadir Kasalak-Yusuf Yıldırım, “Türk Siyasi Hayatında Türkiye Odaları ve Borsalar Birliğinin Yeri: 1950-1954 Dönemi”, Kesit Akademi Dergisi, C. III, S. 12, Aralık 2017, s. 645.

${ }^{81}$ BOA. HR. İM. 195/105, 14 Ağustos 1926.

${ }^{82}$ TBMM Zabıt Ceridesi, Devre VI, C. 30, İçtima 4, Yirmialtıncı inikat, 11. 1. 1943, s. 127.

${ }^{83}$ TBMM Zabit Ceridesi, Devre VI, C. 30, İ. 4, 1943, s. 130.
} 
faaliyet gösterecekti. ${ }^{84}$ Ankara hükümetinin aldığı karar doğrultusunda bundan böyle İstanbul Fransız Ticaret Odası "Şambr dö Komers dö Konstantinopl Cemiyeti"," adıyla yani Türkçe okunduğu gibi faaliyetlerine yeni tüzük ve yapısıyla devam etti. Benzer şekilde İngiliz Ticaret Odası da İstanbul İngiliz Çembir of Comers Cemiyeti” şeklinde yeniden faaliyetlerine başladı. ${ }^{86}$ Odanın yayımlamış olduğu bülten de 1929 'dan günümüze aynı ad ile yayın hayatını sürdürdü. ${ }^{87}$

1870 yıllarda yabancı ticaret odalarının İstanbul'da henüz kurulmaya başladığı yıllarda Osmanlı idarecileri benzer çekince ve kaygılarla bir layiha kaleme almışlar ve bunu Babıali'ye sunmuşlardı. Batılılar bu kuruluşları kapitülasyonlar hukuku çerçevesinde ele aldıklarından bu odaların kurulması engellenememiş ve denetimi de imkânsız hâle geldiğinden bütün yabancı ticaret odaları, şahsi ticaret, yatırım ve rekabetleri için serbest ve denetimsiz bir şekilde faaliyetlerini sürdürmüştü. Cumhuriyet idarecilerinin ise Osmanlı dönemindeki tecrübelerden ders alarak, kapatmasalar dahi en azından bu kurumların isim değişikliğiyle derneklere ve cemiyetlere dönüşmesini sağladıkları, ticaret ve sanayi odası olarak tek mercii Türk Sanayi ve Ticaret Odası olarak yetkilendirdikleri ve dernek veya cemiyet adı altında varlıklarını devam ettiren yabancı ticari müesseseleri daha sıkı bir denetim altına aldıkları tespit edilmektedir. Cumhuriyet idarecilerinin millî ekonomi hususunda izlemiş oldukları sert ve katı siyaseti tecrübe eden başta Fransız olmak üzere tüm yabancı ticaret odaları faaliyetlerini günümüze kadar dernek ve cemiyet olarak sürdürmüşlerdir. Bu bağlamda İstanbul Fransız Ticaret Odası faaliyetlerini bugün de Türk-Fransız Ticaret Derneği adı altında yürütmektedir. Mamafih derneğin kurumsal sitesinde Fransızca olarak kurumun adı La Chambre de Commerce Français en Turquie yani Fransız Türkiye Ticaret Odası olarak belirtilmektedir. ${ }^{88}$

\section{Sonuç}

Sınai kapitalizmle eş zamanlı olarak gelişen demir, kara ve deniz taşıtlarının dünyanın birçok noktasıyla düzenli ve sürekli olarak münasebet sağlaması, Batı metropolleriyle deniz aşırı mekânları birbirine yakınlaştırdı. Bununla aradığı fırsatı yakalayan Batı ekonomisinin sıra dışı şekilde hızlı bir yayılma ve teşkilatlanma sürecine girmesi, sermaye çağının çok yönlü ve fonksiyonlu şirketlerinin ihtiyaçlarını sağlayacak yeni kurumlara olan ihtiyacı had safhaya ulaştırdı. Öncülüğünü Britanya ve Fransa'nın yaptığı Akdeniz ve Atlantik Avrupası'na ait deniz aşırı sömürgelerin sınırlarının netleşmeye başladığı 19 . yüzyılda sömürgelerle sağlanan ekonomik münasebetler, bir noktaya kadar kadim alışkanlıklar üzerinden yani valiler, konsoloslar, ticarethaneler ve şirket acenteleri aracıllğıyla yapıldı. Ancak Osmanlı, İran, Çin gibi geniş coğrafyalara sahip ülkeler, muhtelif Avrupalı milletlere ait çok yönlü tüccar ve müteşebbislerin pazar ve rekabet sahası hâline geldiğinden geleneksel ticarete has kurum ve müesseselerle bu türden ülkelerde var olabilmek, pazarları elde tutmak ve genişletmek zor ve girift bir hâl aldı. Konsoloslar, ticaret evleri, şirketler, misyonerler ve işbirlikçi azınlıklar üzerinden kıyasıya yaşanan pazar rekabetinin ihtiyaçları doğrultusunda yeni yöntem ve yapılar geliştiren devletler her zaman bir adım önde olmayı başarabildiler. Bu amaç doğrultusunda Batı ekonomisinin dünya üzerindeki yayılmacılığının kurumsal ayağını oluşturan en mühim kurumlardan biri Batılı devletlerin başta Osmanlı Devleti olmak üzere yabancı ülkelerde açmış oldukları ticaret odaları oldu. İmparatorluğun idare merkezinde 1884 y1lında kurulan Fransız İstanbul Ticaret Odası, klasik ticaret ve yatırım ilişkileri sağlayan müesseseleri kendi bünyesinde toplayarak Fransız tüccar, sermayedar ve bunlarla iş birliği içerisinde hareket eden gayrimüslim azınlıklardan müteşekkil tüm üyelerini muntazam yapı içerinde koordinasyonlu ve örgütlü bir hâle dönüştürerek bunlara Fransız ekonomisinin çıkar ve menfaatleri doğrultusunda Osmanlı topraklarında kolay ve hızlı bir şekilde yayılma imkânı sundu. Özellikle odanın 1887

\footnotetext{
${ }^{84}$ TBMM Zabit Ceridesi, Devre VI, C. 30, İ. 4, 1943, s. 128.

${ }^{85}$ Bunun için eklerdeki nüshaya bakınız.

${ }^{86}$ TBMM Zabit Ceridesi, Devre VI, C. 30, İ. 4, 1943, s. 128.

${ }^{87}$ Chambre de Commerce Français de Constantinople, XXXVI. Année, N. 407, Octobre 1929.

${ }^{88}$ Ancak derneğin kurumsal sitesinde Fransızca olarak kurumun adı La Chambre de Commerce Français en Turquie olarak belirtilmektedir. Bunun için bkz. https://www.ccift.com/, erişim tarihi 05.12.2019.
} 
yılından itibaren ayda bir defa olarak yayımladığı oda bülteni (Revue Commerciale du Levant Chambre de Commerce Française de Constantinople), Fransız tüccar ve yatırımcısını Osmanlı coğrafyasına çeken çok önemli bilgi kaynağı ve teşvik edici unsur oldu. İstanbul merkezli kurulan Fransız ticaret odaları kısa sürede Çanakkale, Bursa, İzmir gibi birçok önemli ticaret merkezinde açıldı. İstanbul Fransız Ticaret Odasının Osmanlı vilayetlerinin büyük çoğunluğuna dağılmış olan yüzlerce muhabir üyesinin ticari, zirai, sınai hususlar üzerine düzenli bir şekilde gönderdiği raporlar gerek oda bülteni gerekse doğrudan Fransız tüccar ve yatırımcıya ulaşarak yol gösterdi. Oda bülteninin özellikle 1896 yılından itibaren çoğu sayısında ithalat ve ihracata ilişkin bir ürünü konu edinmesi Fransız müteşebbislere ticaret ve yatırım için çok özel yeni fikirler sundu. Fransız elçi ve konsoloslarının da bu odaların fahri başkanları olması siyasetsermaye birlikteliği ve çıkar ilişkisi açısından önemli bir örnek oldu.

Kapitülasyonlar ve ikili ticaret anlaşmaları etrafında açılan kurumlara bu şekilde bir yenisinin daha eklenmesini Osmanlı idarecileri refleks, biraz da şaşkınlık ve tereddütle karşıladı. Osmanlı yerli ziraat ve ticaret odaları var iken bu kurumlara ne lüzum var şeklinde bir karşı koyuş ile başlayan ani refleks diğer yabancı kurumlara gösterilen tepkiler de olduğu gibi bir süre sonra acziyet ve kabullenişle son buldu. Batılı ülkeler, gösterilen bu tepkiye mütekabiliyetle yaklaşarak Osmanlı ticaret odalarının da Avrupa ülkelerinde açılmasına onay verdiler. ${ }^{89}$ Lakin endüstriyel devrimi yakalamak şöyle dursun bu devrimin pazarı hâline gelen Osmanlı ekonomisinin böyle bir teşebbüse girişmesinin Osmanlı sanayisi ve ticaretine katk1 sağlayacağı da şüpheliydi. Kaldı ki ülke ekonomisinin önemli bir bölümünü elinde bulunduran gayrimüslimler de zaten yabancı ticaret odalarının üyesi ve işbirlikçisi idi. Osmanlı tebaası olan gayrimüslimleri dahi kendi bünyesinde toplayamayan yerli ticaret odalarının, yurt dışında bunu başarmaları çok düşük bir ihtimaldi. 1838 Balta Limanı ve 1881 Muharrem Kararnamesi gibi ağır anlaşmalara imza atmak zorunda kalan Osmanlı idarecileri, yabancı şirket ve kurumlara karşı yaklaşımlarda da millî bir iktisat politikası benimseyemediler, benimseseler de uygulamaya dönüştüremediler. İstanbul Fransız Ticaret Odasını kontrol ve denetim altına alma düşüncesi ancak kapitülasyonları lağveden Türkiye Cumhuriyeti idarecilerine nasip oldu. Cumhuriyet döneminde uyum sağlamak zorunda kalan aktörler tam tersine olacak şekilde yer değiştirdi. Cumhuriyet idarecilerinin millî sanayi ve ekonomi politikalarına şiddetle kaşı koyan başta Fransızlar olmak üzere diğer Batılı devletler öncelikle büyük bir tepki gösterseler de bir süre sonra bu tepki zorunlu bir kabullenişe döndü. Türk ekonomisinden ziyade kendi ülkelerinin çıkar ve menfaatleri doğrultusunda faaliyet gösterdiği tecrübe edilen yabancı ticaret odaları 2 Mayıs 1925 yılında TBMM'de alınan karar gereği kapatıldı. Bundan böyle tüm yabancı ticaret odalarının oda statüsünde değil de Ticaret Vekâletinin kontrol ve denetimi altında ancak cemiyet ve dernek statüsünde ve Türk-Fransız ticaretinin ortak menfaatleri doğrultusunda faaliyet göstermek şartıyla varlıklarını devam ettirebilmelerine müsaade edildi. İstanbul Fransız Ticaret Odası da diğer odalar gibi bundan böyle "Şambr dö Komers dö Konstantinopl Cemiyeti”* olarak varlığını devam ettirdi. Günümüzde ise Türk-Fransız Ticaret Derneği [resmî sitesinde ise Fransizca ad 1 Chambre de Commerce Française en Turquie (CCI France Turquie) şeklinde geçmektedir] olarak yoluna devam etmektedir. ${ }^{90}$ Oda statüsü ise yasalar gereği yalnızca yerli ziraat ve sanayi odalarına verildi.

\section{Kaynaklar}

\footnotetext{
${ }^{89}$ Osmanlı'dan Cumhuriyet'e kadar Avrupa kentlerinde açılan ticaret odaları ve bunların faaliyetleri müstakil bir çalışmaya konu olabilecek kadar geniştir. Bununla ilgili Osmanlı ve Cumhuriyet arşivinde çok sayıda malzeme bulunmaktadır.

* Cemiyet olarak isim değişikliğine giden odanın bülteni de yine bu isim altında yayımlandı. Bunun için eklere bakınız.

${ }^{90}$ https://www.ccift.com/; Türkçe resmî sitesi için bkz. https://www.ccift.com/tr.html; erişim tarihi 14. 01. 2020.
} 


\section{Bașbakanlık Osmanlı Arșivi}

Y. EE (Yıldız Esas Evrak1) 149/133.

BEO. (Babiali Evrak Odas1) 3007/225497.

DH. MKT. (Dâhiliye Mektubi) 30/27.

HR. TO. (Hariciye Tercüme Odas1) 368/67.

HR. İM. (Hariciye Nezareti İstanbul Murahhaslığı) 195/105, 14 Ağustos 1926.

\section{ACCIM (Archives de la Chambre de Commerce et d'Industrie Marseille)}

ACCIM. MQ55/104, La Création d'une Chambre Française a Constantinople, août-octobre 1884.

ACCIM. MQ55/104, La Création d'une Chambre Française a Constantinople, Réunion des Notabes Commerçaints 6 octobre 1884.

ACCIM. MQ55/104, La Création d’une Chambre Française a Constantinople, Séance du 10 Octobre 1884, Réunion du conseil

ACCIM. MQ55/104, J. Thouzery'den (Marsilya) Ticaret Odası Başkanı'na, 27 Ekim 1884.

ACCIM. MQ 55/104, Rapport Commercieux des Agents Diplomatiques et Consulaires de France, N. 271, Année 1895.

ACCIM, MQ55/104, Ministere de l'Agriculture et du Commerce, Paris 28 Ocak 1869.

ACCIM. 55/104, 13 Fevrier 1890, Monsieur Girard, President du Conseil Ministre du Commerce de l'Industrie et des Colonies Paris.

ACCIM. MQ55/104, Chambre de Commerce Française de Constantinople, N. 3, Constantinople le 15 Juin 1887.

ACCIM. MQ55/104, Cambre de Commerce Française de Constantinople a Mansieur le President de la Cambre de Commerce de (Marseille), 27 Octobre 1884.

ACCIM. 55/104, Turquie d’Asie Mouvement Commercial de Smyrne, Pour l’année 1893.

ACCIM. MQ, 55/103, Ambassade de France pres la Port Ottomane, Arreté concernant la Caravane, 24 Fevrier 1823.

AFL. (Archives de l'Association French Lines)

1997002 4473, Compagnie de Messageries Maritimes Agence de Smyrne, Rapport General de Service Exercice 1880, 1906, Chapitre 1, Personnel.

İBB. Atatürk Kitaplığı Kütüphanesi

BEL(YD) 03093, Notice Historique sur la Chambre de Commerce Française d'Istanbul 18851935, İstanbul 1936.

\section{BNF. (Bibliotheque Nationale de France)}

Le Journal des Chambres de Commerce Revue Mensuel, 2. Année, N. 12, Decembre 1883.

Le Journal des Chambre de Commerce et d'Industrie, No 1., 12. Année, Paris, 10 Janvier 1893.

Chambre de Commerce Française de Symrne, 1. Année, N. 2, 28 Fevrier 1893.

Chambre de Commerce Française de Symrne, 1. Année, N. 2, 28 Fevrier 1893.

Chambre de Commerce Française de Constantinople, 8. Année, No. 7, 30 Septembre 1894. 
Chambre de commerce française de Constantinople, 10. Année, No: 117, 31 Septembre 1896, Constantinople 1896.

Chambre de commerce française de Constantinople, 13. Année, No: 117, 31 Mars 1900, Constantinople 1900.

Chambre de Commerce Français de Constantinople, 16. Année, No. 190, 31 Janvier 1903, Constantinople 1903.

Chambre de Commerce Français de Constantinople, 17. Année, No. 193, 30 Avril 1903, Constantinople 1903.

Chambre de Commerce Français de Constantinople, 17. Année, No. 194, 31 Janvier 1903, Constantinople 1903.

Chambre de Commerce Français de Constantinople, 17. Année, No. 203, 29 Février 1904, Constantinople 1904.

Chambre de Commerce Français de Constantinople, 17. Année, No. 204, 31 Mars 1904, Constantinople 1904.

Chambre de Commerce Français de Constantinople, 18. Année, No. 216, 31 Mars 1905, Constantinople 1905.

Chambre de Commerce Français de Constantinople, 19. Année, No. 217, 31 Avril 1905, Constantinople 1905.

Chambre de Commerce Français de Constantinople, 20. Année, No. 230, 31 Mai 1906, Constantinople 1906.

Chambre de Commerce Française de Constantinople, 20e. Année, No. 239,28 Fevrier 1907, Constantinople 1907.

Chambre de commerce française de Constantinople, 26. Année, No: 309, 31 Décembre 1912, Constantinople 1912.

Chambre de Commerce Français de Constantinople, 25. Année, No. 300, 31 Mars 1912, Constantinople 1912.

Chambre de Commerce Français de Constantinople, 27. Année, No. 324, 31 Mars 1914, Constantinople 1914.

Chambre de Commerce Française de Constantinople, 35 Y1l sayısı, XXXV eme. Année, No. 378, Janvier-Fevrier 1925, Imp. Française L. Mourkides, Rue Luledji Hendek 125, Constantinople 1925.

Chambre de Commerce Française de Constantinople, 36 Année, No. 407, Octobre 1929, Constantinople 1929.

Répertoire des Travaux de la Société de Statistiques de Marseille, Publié sous la Direction de Adrien Sicard, Marseille 1890.

\section{Salt Galata Kütüphanesi ve Arşivi}

Chambre de Commerce Française de Constantinople Bulletin Memsuel, 1. Année, No. 7, 20 Octobre 1887, Constantinople 1887.

\section{Kaynak ve Tetkik Eserler}

Ahmet Lûtfi Efendi, Vak'anüvis Ahmet Lûtfi Efendi Tarihi, hzl. Yücel Demirel, 1-7-8, Tarih Vakfi Yapı Kredi Yay., İstanbul 1999. 
Akyıldız, Ali, Anka'nın Sonbaharı Osmanlı'da İktisadi Modernleşme ve Uluslararası Sermaye, İletişim Yay., İstanbul 2005.

Chambre de Commerce d'Istanbul, Année 125, Istanbul 2006.

Dalloz, Jurisprudence Generale, Bureau de la Jurisprudance generale, Paris 1902.

Department of Commerce and Labor, No. 2294, Daily Consylar Reports, June 27, Goovernment Printing Office, Washington 1905.

Geyikdağı, Necla, Osmanlı Devleti'nde Yabancı Sermaye 1854-1914, Hil Yay., İstanbul 2008.

Giraud Hubert, Les Origines et l'Evolution de la Navigation a Vapeur a Marseille (1829-1900), Societe Anonyme du Semoplhore de Marseille 1929.

Gülsoy, Ufuk -Bayram NAZIR, Türkiye'de Ticaretin Öncü Kuruluşu, İstanbul Ticaret Odası 1923-1960, İstanbul Ticaret Odas1 Yay., İstanbul 2012.

Güngör, Hakan, “ABD Büyükelçisi Joseph C. Grew’un Karadeniz Seyahati ve Gözlemleri,” ODÜ SOBIAD, 8(3), Kasim 2018, s. 579-586.

Hobsbawm, E. J., The Age of Capital 1848-1875, Weidenfeld and Nicolson Ltd. London 1975.

Hobsbawm, Sermaye Çă̆ı 1848-1875, çev. Bahadır Sina Şener, Dost Yay., İstanbul 2003.

Kasalak, Kadir -Yusuf Yıldırım, "Türk Siyasi Hayatında Türkiye Odaları ve Borsalar Birliğinin Yeri: 1950-1954 Dönemi”, Kesit Akademi Dergisi, C. III, S. 12, Aralık 2017, s. 636-656.

Koraltürk, Murat, “Osmanlı Devleti’nde Ticaret ve Sanayi Odalarının Kuruluşu ve Gelişimi”, Yeni Türkiye Osmanl, C. III, Yeni Türkiye Yay., Ankara 1999, s. 449-458.

Lozan Barış Konferansı Tutanaklar Belgeler, çev. Seha L. Meray, I. Takım, C. II, YKY, İstanbul 1993.

Muahedat Mecmuası, I., TTK Yay., Ankara 2008.

Ortaylı, İlber, Lonca'dan Odaya: İstanbul Ticaret Odasının 125 Yıl Anısina, İstanbul Ticaret Odas1 Yay., İstanbul 2006.

Öndeş, Osman, Vapur Donatanları ve Acenteleri Tarihi, İMEAK Deniz Ticaret Odası, İstanbul 2013.

Pamuk, Şevket, Osmanlı Türkiye İktisadi Tarihi, İletişim Yay. İstanbul 2003.

Revue des Commerce, C. IV, Paris 1909.

Quataert, Donald, Osmanlı Devleti'nde Avrupa İktisadi Yayılımı ve Direniş (1881-1908), (Çev. Sabri Tekay), Yurt Yay., Ankara 1897.

TBMM Zabit Ceridesi, Devre VI, C. 30, İ. 4, 1943, s. 128.

Toprak, Zafer, “Osmanlı'da Ecnebi Ticaret Odaları”, Finans Dünyası, Şubat 1990.

Uygun, Süleyman, “Modern Mısır'ın Doğuşu (Yatırım, Kredi ve İflas Denklemi’nde) ve Bir Fransiz Aktör: Edouard Andre Dervieu", Studies of the Ottoman Domain, C. IX, S. 17, Ağustos 2019, s. 95.

\section{İnternet siteleri}

https://www.cci.fr/web/organisation-du-reseau/histoire, erişim tarihi 25.07.2019.

https://www.ccift.com/, erişim tarihi 05. 12. 2019. 


\section{İstanbul Fransız Ticaret Odasının Cumhuriyet Döneminde Cemiyete Dönüșmesi ve Bunun Gazetesine Yansıması}

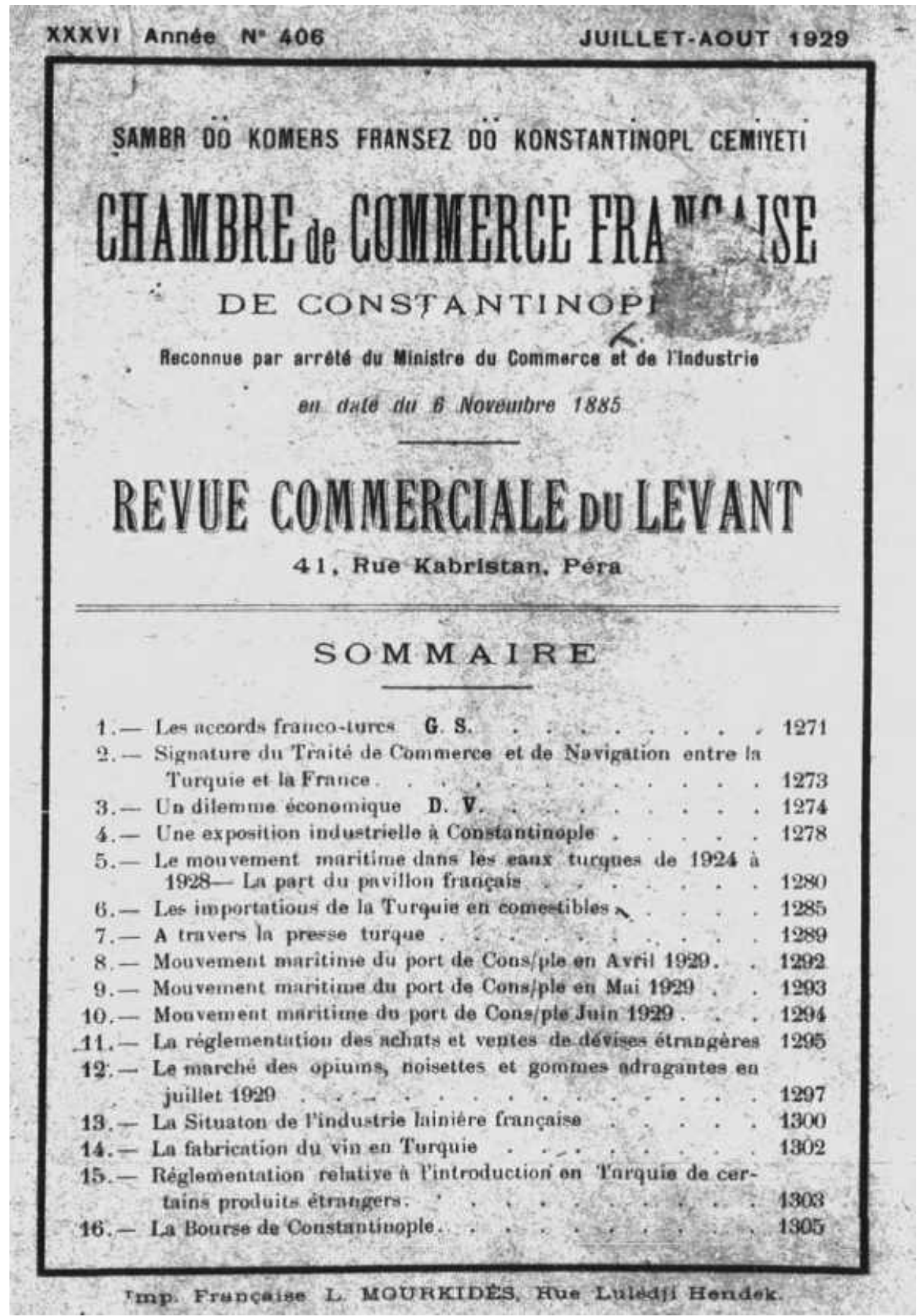

Kaynak: Chambre de Commerce Française de Constantinople 36. Y11, No 406, Temmuz-Ağustos 1929. 
İstanbul Ticaret Odası İdare Meclisi (1936) (Soldan 3. Sırada oturan Başkan M. Laurent Reboul)

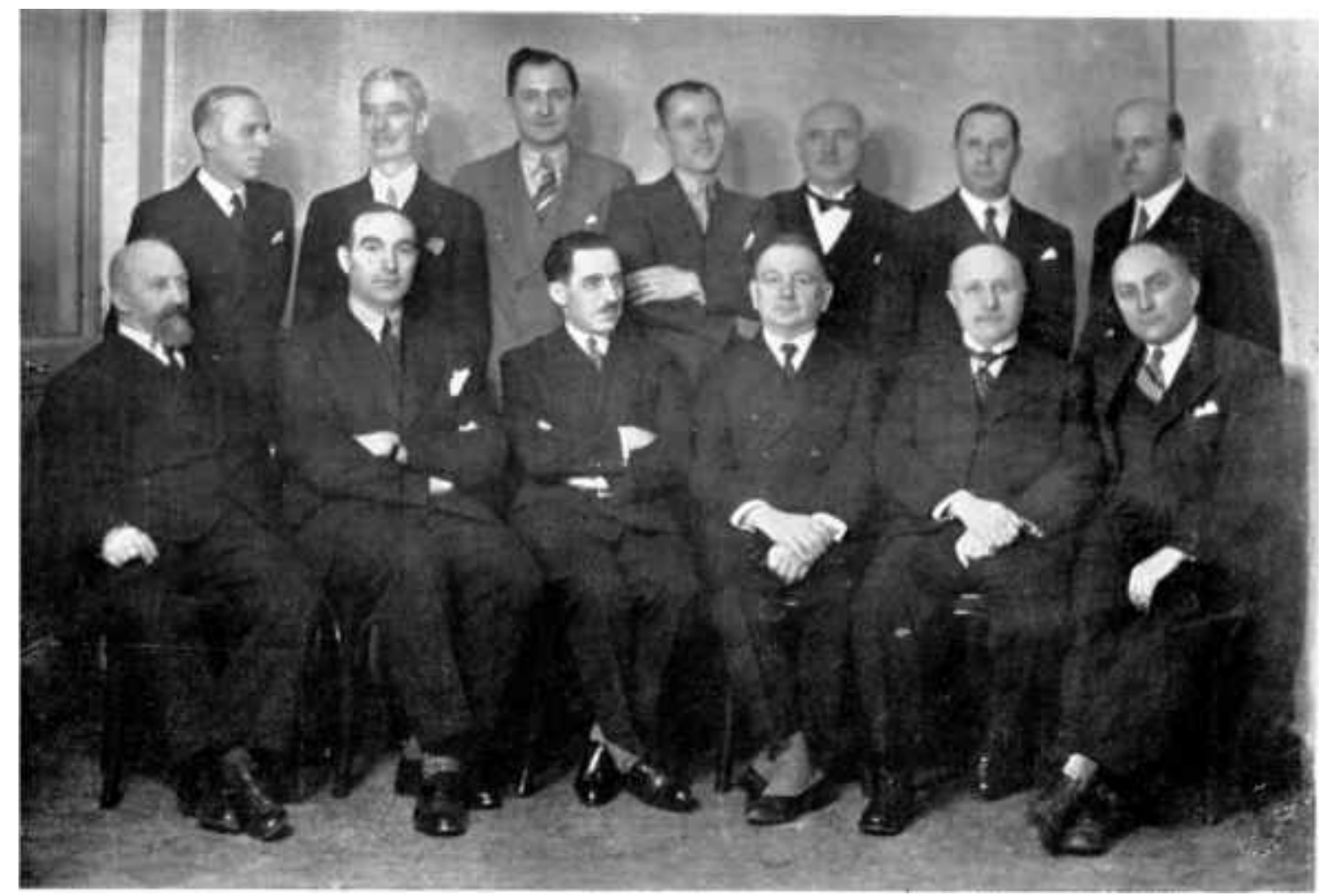

Kaynak: Notice Historique sur la Chambre de Commerce Française d'Istanbul, s. 6-7. 


\section{Fransız Ticaret Odasının Kuruluş Nizamnamesi (1884)}

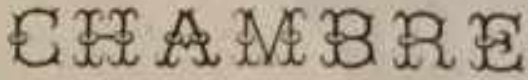 \\ $\mathrm{DE}$ \\ COMMERCE \\ FRA NCAAISE}

A CONSTANTINOPLE.

\section{CONSTANTINOPLE}

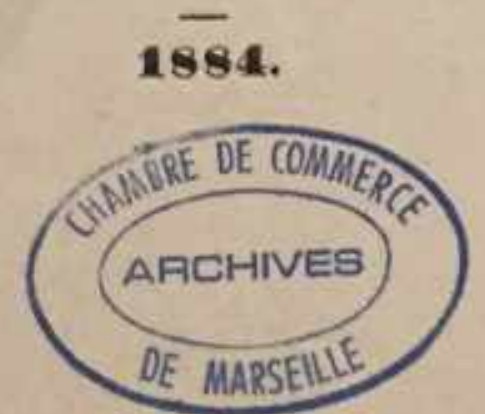

Kaynak: ACCIM. MQ55/104, Compte rendus des réunions décidant la création d’une Chambre de Commerce français a Constantinople, Août-octobre 1884. 


\section{Summary}

The Turkish-French maritime commerce relations have taken an important place in the economic, political, and socio-cultural dimension throughout the history. The granted capitulations since 1535 had a significant importance and influence in the development of these relations. Since the decline of the Ottoman Empire, the functioning of the capitulations began to become a burden upon the Ottoman Empire. Especially with the Industrial Revolution, the Ottoman-French relations entered in a new and different phase. In a period of industrial breakthrough, the Ottoman Empire removed the customs barriers against imported products with the agreement of Balta Harbor, Convention of 1838 and its subsequent trade agreements, thus it became an indispensable market of the European industry. In a fast and powerful way, this facilitated the control of the European economy on the Ottoman port cities. Relations based on old business were replaced by new institutions in the Industry Age. Since the second half of the $19^{\text {th }}$ century, the competition in the Ottoman geography, which witnessed the spread of many foreign companies and institutions, allowed the opening and competition of many new institutions belonging to various nations.

The communication network, based on correspondence from the envoy, ambassadors, consuls and Levantine merchants scattered across the main port city of the east remained incapable and cumbersome in the face of the rapid and expansionist nature of industrial capitalism and the liberal economy. Further, they couldn't keep up with this change. Information from ambassadors and consuls could not meet the needs of rapidly growing trade houses and companies. At this stage, the states tried to find solutions by appointing company agents as consuls or vice-consuls. However, this practice could not meet the expectations sufficiently.

One of the important institutions opened to fill this gap was the foreign chambers of commerce. European states maintained all kinds of their commercial and economic organizations through their Chambers of Commerce. Then, they started to open these institutions in the markets and colonies where they had commercial and economic relations from the second half of the $19^{\text {th }}$ century. In this framework, they started to open chambers of commerce in the Ottoman capital as of 1870. Many states Eur owned chambers of commerce, such as Austria, Great Britain, Germany and Italy, quickly expanded to Ottoman port cities. In 1884, the French joined the process by opening a Chamber of Commerce in Istanbul. The activities of the Chamber of Commerce were generally to attract the French investor to the region, to coordinate the relations between them, and to inform about all kinds of commercial, agricultural, political, social, and economic issues.

The Ottoman Empire was able to open institutions such as the chambers of commerce opened by the western countries only as late as 1880. Since the guild system, whose effectiveness and function weakened in the $19^{\text {th }}$ century, was unable to adapt to the Liberal economy, it started to be replaced by chambers of commerce, agriculture, and industry. The Ottoman State, which was forced to be included in the institutionalization process in the free market economy, opened such an institution on 19 January 1880 with the proposal of Said Pasha. In the founding legislation of the Istanbul Chamber of Commerce, Agriculture and Industry, a separate emphasis was given to the development of trade, industry, culture and art, like the French chambers of commerce. However, members and activities of the Istanbul Chamber of Commerce, Agriculture and Industry remained very limited. Because non-Muslims and foreigners who had influenced in the Ottoman economy was mostly members of foreign trade chambers. For this reason, to the local chambers of commerce were not in demand such as foreign chambers of commerce.

One of the most important activities of the Istanbul French Chamber of Commerce was its newspaper, which it publishes regularly once a month. The newspaper, published as "Revue Commerciale du Levant Chambre de Commerce Française de Constantinople" once a month as of 1887, detailed information on agriculture, trade, agriculture, economics, maritime and postal 
transport. The newspaper's news source was correspondent members in cities in the Levant and Black Sea hinterland. These generally consisted of French consuls and assistants, dragomans, Ottoman Bank, Public Debts (Duyun-1 Umumiye) Administration and Regie of Ottoman Tobacco Company managers and officers, important merchants and entrepreneurs. The members of the chamber, which spread across a wide geography as from the Balkans to Odessa, Petersburg, and the Caucasus from Samsun to Giresun, Trabzon, Erzurum, Kayseri, Konya, Adana, İzmir, Diyarbakır, Cyprus, Syra, Tripoli, and Beirut, gave detailed information about the Ottoman commerce and economy. By the end of the 19th century, French Chambers of Commerce were opened in most Mediterranean port cities, especially in Izmir and Alexandria.

The newspaper discussed most of the products that were the subject of the Ottoman trade in provinces since 1896. Various oils, alcoholic beverages, milk and dairy products, cereals such as barley, wheat; potatoes, flour, eggs, indigo, metals, hat, clothes, musical instruments, machinery, instrument, perfume, chocolate, cocoa, wine, cotton, honey, spinning machine, thread, scissors, etc. products were the subject of the newspaper.

The newspapers introduced these Ottoman products and potential wealth of the country to Western traders and entrepreneurs. Thus, investors were informed about potential market in the Ottoman State. French Merchants, who did not want to miss this opportunity, spread all over the Ottoman geography. In a special issue of the newspaper published by the Istanbul French Chamber of Commerce in its tenth anniversary, it was stated that the French Chamber's activity operated in 140 ports and 49 trade centers. The newspaper also provided detailed information on marine transportation, and shipping companies. In this way, it encouraged the spread of the French economy in an organized and coordinated manner in the Ottoman geography by meeting the expectations and needs of traders and investors. Foreign trade chambers, which collect all the sources of agriculture, trade, and industry in the Ottoman Empire, played a direct role in shaping the Ottoman economy.

Although the Ottoman administrators tried to control the activities of the Chamber of Commerce, they were not very successful. However, with the establishment of the Republic of Turkey, Istanbul French Chamber of Commerce autonomous structure and status were changed. The autonomous structure and status of the Istanbul French Chamber of Commerce was taken under control when the Turkish Government revoked the capitulations. This commercial institution had to adapt to the national industrial and economic policy of the Republic. Despite all these adaptation processes and efforts, all the foreign chambers of commerce were closed based on the decision taken in the Turkish Grand National Assembly on 2 May 1925. After that, all foreign chambers of commerce were taken to the status of association. They were allowed to continue their activities on the condition that they operate in line with the common interests of the Turkish-French trade. The French Chamber of Commerce continued to exist as an association (Şambr dö Komers dö Konstantinopl Cemiyeti), just like other foreign chambers. Today, it continues its activities as the Turkish-French Trade Association. (However, in the official website of the association, its French name is Chambre de Commerce Française[CCI France Turquie] en Turquie). In this regard, the French Chamber of Commerce, which was established during the Ottoman Empire and existed until the Republic of Turkey, is the subject of this study. 